\title{
Abstracts najaarsvergadering NVU, 2 november 2018, Nieuwegein
}

\section{1. 'High-Definition' Prostaat Specifiek Membraan Antigeen PET/CT en interobserver-overeenkomst: kan de diagnostische accuratesse omhoog?}

B.H.E. Jansen, R.W. Jansen, M. Wondergem, S. Srbljin, J.M.H. de Klerk, A.N. Vis, R.J.A. van Moorselaar, R. Boellaard, O.S. Hoekstra en D.E. Oprea-Lager Amsterdam UMC, locatie VUmc, Amsterdam; Noordwest Ziekenhuisgroep, Alkmaar/Den Helder; Zaans Medisch Centrum, Zaandam; Meander MC, Amersfoort

\section{Introductie}

Biochemisch recidiverende prostaatkanker (BCR) is de belangrijkste indicatie voor het uitvoeren van prostaatspecifiek membraan antigeen PET/CT (PSMA PET/CT). Hoewel PSMA PET/CT een sensitief diagnosticum is, blijft het lokaliseren van BCR bij lage PSA-waarden problematisch. Naast $\left[{ }^{68} \mathrm{Ga}\right]$ PSMA PET wordt $\left[{ }^{18} \mathrm{~F}\right] \mathrm{PSMA}$ PET $\left(\left[{ }^{18} \mathrm{~F}\right] \mathrm{DCFPyL}\right)$ in toenemende mate gebruikt, omdat het een hogere beeldresolutie faciliteert. Dit is de eerste studie die onderzoekt of (1) hoge-resolutie $\left[{ }^{18} \mathrm{~F}\right] \mathrm{PMSA}$ PET/CT-beelden de lokalisatie van $\mathrm{BCR}$ verbeteren bij patiënten met lage PSA-waarden en (2) wat de interobserver- overeenkomst is van $\left[{ }^{18} \mathrm{~F}\right] \mathrm{PSMA}$ $\mathrm{PET} / \mathrm{CT}$.

\section{Materiaal en methoden}

Twaalf patiënten met een $\mathrm{BCR}$ na robotgeassisteerde radicale prostatectomie werden geïncludeerd (huidig PSA $<2,0 \mathrm{ng} /$ $\mathrm{ml}$ ). PET-beelden werden gemaakt met $4 \mathrm{~mm}$ pixels (klinische standaard) en $2 \mathrm{~mm}$ pixels (high definition). Deze beelden werden gemaakt met en zonder Point-Spread-Functions (PSF), een beeldtechniek gericht op detectie van kleine laesies. Alle scans werden onafhankelijk en geblindeerd door vier nucleair geneeskundigen uit verschillende centra beoor-

\footnotetext{
$\triangle$ Prof. dr. P.F.A. Mulders

peter.mulders@radboudumc.nl

Radboudumc, Nijmegen, Nederland
}

Tijdschrift voor Urologie,

Bohn Stafleu van Loghum, Houten, Nederland deeld. Om uit te sluiten dat moderne PET-beelden tot fout-positieve laesiedetectie leiden, werden vijf patiënten geïncludeerd met primaire prostaatkanker en histologisch bewezen negatieve lymfeklierstatus (N0, na lymfeklierdissectie).

\section{Resultaten}

In totaal werden 192 PSMA PET/CT-scans voor BCR geanalyseerd (12 patiënten $\mathrm{x} 4$ type PET-beelden $\mathrm{x} 4$ nucleair geneeskundigen). Een mogelijke lokalisatie van BCR werd gevonden bij 72,9\% van alle scans (140/192). De proportionele interobserver-overeenkomst was $86,1 \%(95 \%-\mathrm{BI}=80,9$ $90,4)$. Significant meer scans waren positief met de $2 \mathrm{~mm}-$, dan met de $4 \mathrm{~mm}$-beelden ( $81,3 \%$ versus $64,6 \% ; p=0,005$ ). PSF verbeterde de detectie niet. Er werden 13 fout-positieve laesies gedetecteerd in de groep met primaire prostaatkanker, gelijkelijk verdeeld over de verschillende beeldtechnieken.

\section{Conclusie}

De lokalisatie van BCR bij patiënten met lage PSA-waarden neemt toe bij gebruik van $2 \mathrm{~mm}$ - $\left[{ }^{18} \mathrm{~F}\right] \mathrm{PSMA}$ PET/CT-beelden,

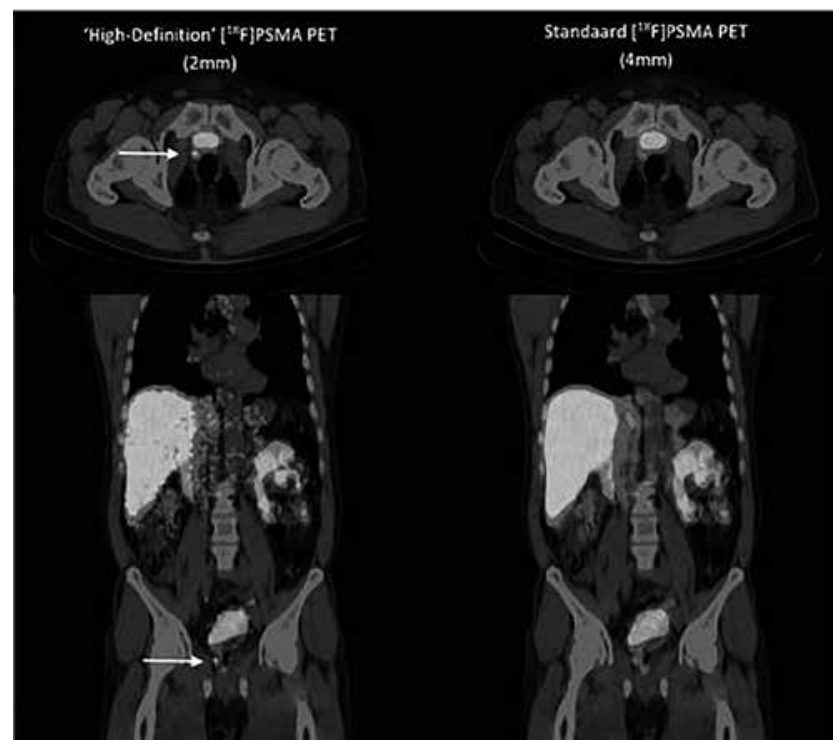

Figuur 1.1 Voorbeeld van de lokalisatie van BCR met 'High-Definition' en standaard [18F]PSMA PET/CT beelden. Alleen op de 2mm PET beelden werd het lokaal recidief waargenomen (zie pijlen). 
zonder toename in fout-positieve bevindingen. De interobserver-overeenkomst van $\left[{ }^{18} \mathrm{~F}\right]$ PSMA PET scans is goed.

\section{De Nederlandse vertaling en validatie van de Multiple Sclerosis Intimacy and Sexuality Questionnaire (MSISQ-15), een vragenlijst naar het seksueel functioneren bij multiple sclerosis (MS) en dwarslaesiepatiënten}

\author{
T.C. Noordhoff, J.R. Scheepe, L.A. 't Hoen, T.A.R. Sluis \\ en B.F.M. Blok \\ Erasmus MC, Rotterdam; Rijndam Revalidatie, Rotterdam
}

Een neuro-urologische (NU) aandoening kan significante consequenties hebben op het seksueel functioneren en de kwaliteit van leven. Een gevalideerde Nederlandse vragenlijst om seksuele disfunctie in deze patiëntenpopulatie te evalueren ontbreekt. Het doel van deze studie is het vertalen en valideren van de MSISQ-15 voor het gebruik bij patiënten met multipele sclerose (MS) of ruggenmergaandoening in Nederland.

\section{Materiaal en methoden}

De cross-culturele adaptatie van de Engelse MSISQ-15 naar het Nederlands werd verricht volgens standaard richtlijnen. Op de polikliniek Urologie en Revalidatiegeneeskunde werden seksueel actieve patiënten met MS of ruggenmergaandoeningen, zoals een dwarslaesie of cauda equina syndroom, gevraagd deel te nemen. Bij inclusie werd de MSISQ-15 ingevuld en als referentiemaat de Pelvic Organ Prolapse/Urinary Incontinence Sexual Questionnaire (PISQ-12) door vrouwen en de International Index of Erection Function (IIEF-15) door mannen. Een tot twee weken later werden de vragenlijsten nogmaals ingevuld. De controlegroep bestond uit patiënten die de huisarts bezochten. Deze patiënten vulden de vragenlijst eenmalig in. Content-, criterium-, constructvaliditeit, interne consistentie en reproduceerbaarheid werden geanalyseerd.

\section{Resultaten}

De testfase toonde adequate contentvaliditeit, de vragenlijst is duidelijk en omvat de problemen omtrent het seksueel functioneren bij een NU-aandoening. In totaal werden 53 patiënten met MS, 49 patiënten met een ruggenmergaandoening en 50 controles geïncludeerd. In de patiëntengroep was de MSISQ-15-score gecorreleerd aan de mate van seksueel disfunctioneren gemeten met de PISQ-12 en de IIEF-15, wat wees op goede criteriumvaliditeit. MSISQ-15-scores in de patiëntengroep $(38,9 \pm 11,4)$ waren hoger dan in de controle groep $(21,1 \pm 5,4 ; p<0,001)$. Dit bevestigt een goede constructvaliditeit. De MSISQ-15 toonde goede interne consistentie (Cronbachs alfa $>0,8$ ) en reproduceerbaarheid (intraclass-correlatiecoëfficënt $>0,8$ ).

\section{Conclusies}

De Nederlandse MSISQ-15 is betrouwbaar en valide voor het evalueren van seksuele disfunctie bij patiënten met MS of een ruggenmergaandoening te evalueren.

\section{Praktijkvariatie in initiële diagnostiek van prostaatcarcinoom binnen de Santeon- ziekenhuizen}

T. Soeterik, B. Ament, L. Dijksman, H. van Melick, E. Vrijhof, G. van Andel, A. Meijer, S. Klaver, R. Korthorst, S. Stomps, D. Luijendijk en J-P van Basten St. Antonius Ziekenhuis, Nieuwegein/Utrecht; CWZ, Nijmegen, Catharina Ziekenhuis, Eindhoven, OLVG Amsterdam, Maasstad Ziekenhuis, Rotterdam; Martini Ziekenhuis, Groningen, Medisch Spectrum Twente, Enschede, ZGT Twente, locatie Hengelo/ Almelo

\section{Introductie}

Uit het Value Based Health Care project van de Santeon ziekenhuizen is gebleken dat er grote praktijkvariatie is in de behandeling van lokaal prostaatcarcinoom (PCa) en dat uitkomsten na behandeling sterk kunnen variëren tussen ziekenhuizen. Deze praktijkvariatie bleek niet te herleiden tot verschil in case-mixfactoren, leeftijd en d'Amico-classificatie. Mogelijk wordt dit verklaard door andere factoren, zoals variatie in diagnostische work-up.

\section{Methode}

Middels een online enquête onder de Santeon-urologen werd mogelijke variatie in praktijkvoering betreffende diagnostisch onderzoek (MRI, PET/CT, botscan en pelviene lymfeklierdissectie [PLND]) in kaart gebracht. Tevens werd de initiële diagnostische work-up bij patiënten met PCa vergeleken tussen de ziekenhuizen. Hiertoe werden patiënten geïncludeerd die in 2017 in het eigen ziekenhuis met PCa waren gediagnosticeerd. Potentiële correlaties tussen diagnostische work-up en behandeluitkomsten werden onderzocht.

\section{Resultaten}

De enquête werd ingevuld door 29 urologen en toonde verdeeldheid betreffende de indicatiestelling voor MRI van de prostaat: $57 \%$ verricht altijd een MRI en $43 \%$ enkel op indicatie. Daarnaast verschilde de indicatiestelling voor een pelviene lymfeklierdissectie: de gehanteerde afkapwaarde van het MSKCC-nomogram varieerde van $>5 \%$ tot $>15 \%$. Analyse van 842 patiënten bevestigde de variatie in het gebruik van de verschillende diagnostische modaliteiten. Het percentage patiënten dat werd behandeld met een RARP, en tevens een PLND onderging, varieerde sterk per ziekenhuis (tabel 3.1). Daarnaast ondergingen in ziekenhuis 3 88\% van 
Tabel 3.1 Verschillen tussen ziekenhuizen ten aanzien van ingezette diagnostiek per risicogroep.

\begin{tabular}{|c|c|c|c|c|c|c|}
\hline ziekenhuis & 1 & 2 & 3 & 4 & 5 & $p$ \\
\hline \multicolumn{7}{|c|}{ totaal aantal patiënten $(n=842)$} \\
\hline & 150 & 126 & 152 & 170 & 244 & \\
\hline \multicolumn{7}{|c|}{ MRI-prostaat (\%) } \\
\hline overall & 83 & 85 & 88 & 28 & 77 & $<0,001$ \\
\hline laag risico & 84 & 79 & 81 & 35 & 93 & $<0,001$ \\
\hline intermediair & 84 & 87 & 96 & 27 & 74 & $<0,001$ \\
\hline hoog risico & 83 & 89 & 83 & 23 & 65 & $<0,001$ \\
\hline \multicolumn{7}{|l|}{$\mathrm{PET} / \mathrm{CT}(\%)$} \\
\hline overall & 9 & 1 & 7 & 27 & 17 & $<0,001$ \\
\hline laag risico & 0 & 0 & 0 & 2 & 4 & 0,363 \\
\hline intermediair & 3 & 3 & 7 & 22 & 10 & 0,005 \\
\hline hoog risico & 24 & 0 & 10 & 50 & 35 & $<0,001$ \\
\hline \multicolumn{7}{|c|}{ skeletscintigrafie (\%) } \\
\hline overall & 41 & 37 & 41 & 22 & 27 & $<0,001$ \\
\hline laag risico & 3 & 0 & 3 & 2 & 3 & 0,326 \\
\hline intermediair & 39 & 26 & 15 & 7 & 10 & $<0,001$ \\
\hline hoog risico & 81 & 70 & 86 & 55 & 64 & 0,002 \\
\hline \multicolumn{7}{|c|}{ patiënten behandeld met RARP $(n=228)$} \\
\hline & 40 & 30 & 50 & 61 & 47 & \\
\hline \multicolumn{7}{|c|}{$\%$ patiënten met een RARP dat tevens een PLND onderging } \\
\hline overall & 48 & 53 & 68 & 44 & 38 & 0,039 \\
\hline laag risico & 14 & 30 & 0 & 0 & 0 & 0,044 \\
\hline intermediair & 41 & 46 & 64 & 55 & 23 & 0,048 \\
\hline hoog risico & 89 & 89 & 94 & 92 & 77 & 0,593 \\
\hline
\end{tabular}

alle patiënten een MRI van de prostaat, vergeleken met $28 \%$ in ziekenhuis 4. Het niet ondergaan van een MRI voorafgaand aan RARP was geassocieerd met een verhoogd risico op een positief snijvlak (OR: 4,7; $p<0,001$ ).

\section{Conclusie}

Er is een opvallende variatie tussen Santeon-ziekenhuizen ten aanzien van de initiële diagnostische work-up bij mannen met lokaal prostaatcarcinoom. De geconstateerde verschillen vragen om verantwoording van het diagnostisch beleid en verdere evaluatie van de meerwaarde van de ingezette diagnostiek voor het bereiken van betere uitkomsten.

\section{Voorspellen van urotheelcarcinoom-gradering in de hoge urinewegen op basis van digitale endoscopiebeelden}

J.D. Legemate, J.E. Freund, J. Baard, K. Saeb-Parsy, O. Wiseman, S. Doizi, E. Emiliani. A. Breda, B.J. Boodt, E.P. van Haarst, M.M.G. Leeflang en G.M. Kamphuis Amsterdam UMC, locatie AMC, Amsterdam; Universiteit van Amsterdam, Amsterdam; Cambridge University, Cambridge
Hospitals NHS Trust, Cambridge, Verenigd Koninkrijk; Tenon Hospital, Université Pierre et Marie Curie, Parijs, Frankrijk; Fundacion Puigvert, University Autonoma of Barcelona, Barcelona, Spanje; Flevoziekenhuis, Almere; OLVG, Amsterdam

\section{Introductie}

Urotheelcarcinomen van de hoge urinewegen (UCHU) worden histopathologisch onderverdeeld in laaggradige (LG) en hooggradig (HG) tumoren. Deze gradering is een bepalende factor voor de risicostratificatie en daarmee voor de therapiekeuze. Deze studie onderzoekt in welke mate de visuele beoordeling van UCHU tijdens digitale ureteroscopie de histopathologische gradering correct is.

\section{Materiaal en methode}

Negen urologen uit zes ziekenhuizen, geblindeerd voor klinische informatie, voorspelden aan de hand van 64 video's de histopathologische gradering van 41 LG en 23 HG UCHU. Dertig dagen na de eerste ronde, werden de gerandomiseerde video's nogmaals beoordeeld. De histopathologische gradering van ureteroscopische biopten van de gevisualiseerde UCHU werd als referentiestandaard gebruikt. Hiermee werd de diagnostische accuratesse van de voorspellingen bere- 

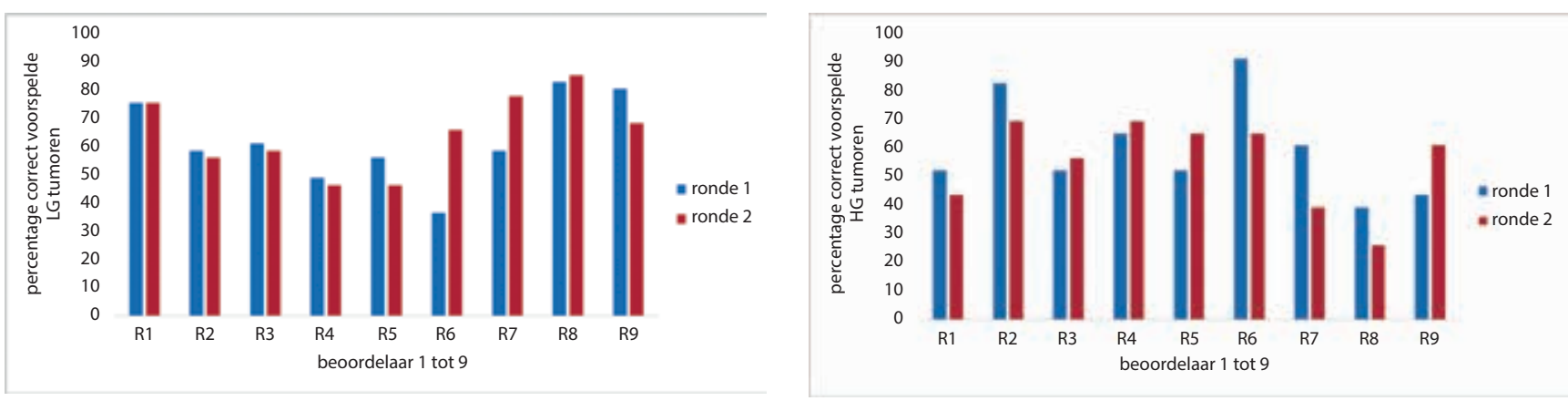

Figuur 4.1 Het percentage correct voorspelde LG- en HG-tumoren gespecificeerd per beoordelaar.

kend. De intraobserver-overeenkomst werd uitgedrukt als het percentage antwoorden dat overeenkwam tussen de eerste en tweede beoordelingsronde van dezelfde beoordelaar. De interobserver-overeenkomst werd uitgedrukt als het percentage antwoorden dat overeenkwam tussen de verschillende urologen. Een intra- en interobserverovereenkomst van $\geq 80 \%$ werd beschouwd als acceptabel.

\section{Resultaten}

De gradering werd door de urologen in 53-67\% van de gevallen correct voorspeld. LG-tumoren werden correct voorspeld in $37-85 \%$ van de gevallen, met een mediaan van $59 \%$ in de eerste ronde en $61 \%$ in de tweede ronde. HG-tumoren werden correct voorspeld in $26-91 \%$ van de gevallen, mediaan $52 \%$ in de eerste ronde en $61 \%$ in de tweede ronde (figuur 4.1). De intraobserver-overeenkomst was $55-91 \%$ met een mediaan van $81 \%$. De interobserver-overeenkomst varieerde van $48-83 \%$ met een mediaan van $66 \%$.

\section{Conclusies}

Visuele beoordeling van de UCHU tijdens digitale ureteroscopie resulteert in een groot deel van de gevallen in een onjuiste voorspelling van de histopathologische gradering. Bovendien is de interobserver-overeenkomst van de voorspelling laag. Hieruit volgt dat de klinische besluitvorming voor UCHU niet enkel op de visuele beoordeling van de tumorgradering gebaseerd kan worden.

\section{De meerwaarde van een nomogram ter predictie van zijdespecifieke extracapsulaire extensie bij patiënten met prostaatkanker in de preoperatieve setting}

T.F.W. Soeterik, H.H.E. van Melick, H. Kusters, S. Stomps, L.M. Dijksman, D.H. Biesma, J.A. Witjes en J.P.A. van Basten CWZ, Nijmegen; ZGT Hengelo/Almelo; Martini Ziekenhuis, Groningen; St. Antonius Ziekenhuis, Nieuwegein/Utrecht; Maasstad Ziekenhuis, Rotterdam

\section{Introductie}

De grote uitdaging in de preoperatieve work-up bij patiënten met prostaatkanker die opteren voor een robotgeassisteerde radicale prostatectomie (RARP) is de afweging tussen het bereiken van een optimaal oncologische resultaat versus maximale functionele uitkomst middels zenuwsparing. De kans op aanwezigheid van extracapsulaire extensie (ECE) speelt daarbij een cruciale rol. Daar de accuratesse van de multiparametrische MRI (mp-MRI) mogelijk beperkt is, onderzochten wij de potentiële meerwaarde van een nomogram ter predictie van zijdespecifieke ECE.

\section{Materiaal en methoden}

Patiënten die een RARP ondergingen van 2014 t/m 2017 werden geïncludeerd. Algemene predictoren die waren opgenomen in het logistische regressiemodel waren: leeftijd, Epstein-gradering (graad $1 \mathrm{t} / \mathrm{m}$ 5) en PSA-densiteit. Zijdespecifieke factoren waren: het percentage tumorpositieve biopten (\%), rectaal toucher (T2 of T3 vs. T1) en ECE op mp-MRI (ja/nee). De primaire uitkomst was vaststelling van ECE bij PA-onderzoek. Diagnostische accuratesse van het nomogram werd vergeleken met de mp-MRI. Voor het nomogram werd een afkappunt van $20 \%$ gehanteerd, dat wil zeggen: een berekende kans op ECE van $>20 \%$ werd beschouwd als een positief testresultaat (ECE aanwezig).

\section{Resultaten}

Er werden 657 patiënten geïncludeerd voor analyse. Alle variabelen behalve leeftijd bleken significante voorspellers voor de aanwezigheid van ECE (voor zowel de linker- als de rechterzijde). Het nomogram is superieur vergeleken met de mp-MRI ten aanzien van sensitiviteit (79\% vs. 55\%) en negatief voorspellende waarde ( $92 \%$ vs. $84 \%)$. Met het nomogram zou dus bij een kwart méér patiënten preoperatief ECE kunnen worden vastgesteld. Daarbij neemt het percentage terecht negatieven met gemiddeld $7 \%$ toe vergeleken met de mp-MRI. Gegeven de NPV van $92 \%$ kan met grotere zekerheid ECE worden uitgesloten en kan er dus veilig aan die zijde zenuwsparend worden geopereerd (tabel 5.1). 
Tabel 5.1 Uitkomsten van het ontwikkelde nomogram vergeleken met de multiparametrische MRI van de prostaat

\begin{tabular}{lllll}
\hline & sens (\%) & spec (\%) & NPV (\%) & PPV (\%) \\
\hline ECE links & & & & \\
\hline mpMRI & 55 & 89 & 84 & 65 \\
nomogram* & 79 & 73 & 92 & 49 \\
\hline ECE rechts & & & & \\
\hline mpMRI & 47 & 87 & 84 & 53 \\
nomogram* & 79 & 74 & 91 & 53 \\
\hline
\end{tabular}

$E C E$ extracapsulaire extensie, $m p-M R I$ multiparametric magnetic resonance imaging, sens sensitiviteit, spec specificiteit, $N P V$ negatief voorspellende waarde, $P P V$ positief voorspellende waarde.

* Afkapwaarde voor positief testresultaat: $20 \%$.

\section{Conclusies}

Het ontwikkelde nomogram ter predictie van zijdespecifieke factoren van het prostaatcarcinoom heeft een hogere sensitiviteit en negatief voorspellende waarde vergeleken met mp-MRI. Dit nomogram kan bijdragen aan een betere inschatting van de oncologische veiligheid van het zenuwsparend opereren.

\section{De diagnostische waarde van PSMA PET/CT voor de detectie van lymfekliermetastasen bij primair gediagnosticeerd prostaatcarcinoom}

\author{
F.J. Hinsenveld, E.M.K. Wit, M. Donswijk, E. van Muilekom, \\ C.Tillier, H.G. van der Poel en P.J. van Leeuwen \\ Antoni van Leeuwenhoek, Amsterdam
}

\section{Introductie}

Het huidige conventionele beeldvormende onderzoek is niet sensitief of specifiek genoeg voor de detectie van lymfekliermetastasen (LKM) bij het primair gediagnosticeerd prostaatcarcinoom (PCa). Recente studies hebben de toegevoegde waarde aangetoond van PSMA PET/CT in de diagnostiek van PCa. Doel van deze studie is het vaststellen van de diagnostische waarde van PSMA PET/CT voor de detectie van LKM bij het primair gediagnosticeerd PCa.

\section{Materiaal en methoden}

Tussen januari 2017 en augustus 2018 werden alle patiënten geïncludeerd met een primair PCa, die een PSMA PET/CT ondergingen voorafgaande aan robotgeassisteerde prostatectomie met uitgebreide pelviene lymfeklierdissectie (PLKD). Een PSMA PET/CT werd verricht bij een PSA > $20 \mu \mathrm{g} / \mathrm{l} \mathrm{en} /$ of Gleason-score $\geq 8$.

\section{Resultaten}

Bij 96\% van de 91 patiënten was in de primaire tumor PSMA PET avide. In totaal hadden 21 patiënten $(23 \%)$ LKM bij pathologische evaluatie. Specificiteit en sensitiviteit van PSMA PET/CT waren in de per-patiënt-analyse $96 \%$ en $38 \%$ en op lymfeklierniveau $98 \%$ en $30 \%$, respectievelijk. Bij 3 van de 8 patiënten $(38 \%)$ bij wie de PSMA PET/CT terecht-positieve klieren had aangetoond, werden in de PLKD nog extra LKM gevonden. Drie patiënten hadden een fout-positieve scan, waarvan twee patiënten vermoedelijk een incomplete PLKD hadden, afgaande op herhaalde postoperatieve PSMA PET/CT die dezelfde positieve klier liet zien. In totaal werden er 28 klieren gemist door PSMA PET/CT (fout-negatieven). De LKM die werd gevonden op de PSMA PET/CT (terecht-positieven) waren significant groter dan de fout-negatieven; gemiddeld 5,9 $\mathrm{mm} v s$. $2,7 \mathrm{~mm}(p=0,020)$.

\section{Conclusie}

PSMA PET/CT is hoog specifiek, echter matig sensitief voor het opsporen van LKM bij de primaire stadiëring van PCa. Met name kleine klieren worden gemist, waardoor PSMA PET/CT een beperkt aantal van alle klierpositieve patiënten identificeert. PSMA PET/CT kan de PLKD niet vervangen, desondanks kan het met zijn hoge specificiteit een deel van de patiënten met LKM preoperatief herkennen, waardoor aanpassing van het behandelplan vroegtijdig mogelijk is.

\section{De superieure diagnostische waarde van de schildwachtklierbiopsie bij patiënten met primair gediagnosticeerd prostaatcarcinoom zonder lymfogene metastasering op PSMA PET/CT}

\author{
F.J. Hinsenveld, P.J. van Leeuwen, M. Donswijk, E. van \\ Muilekom, C. Tillier, H.G. van der Poel en E.M.K. Wit \\ Antoni van Leeuwenhoek, Amsterdam
}

\section{Introductie}

De waarde van PSMA PET/CT ten aanzien van stadiëring van het primair gediagnosticeerd prostaatcarcinoom (PCa) is onduidelijk. PSMA PET/CT heeft een hoge specificiteit (95-99\%), maar een matige sensitiviteit (56-64\%) voor de detectie van lymfekliermetastasen (LKM). Een schildwachtklierbiopsie (SKB) heeft echter een hoge diagnostische waarde met een sensitiviteit van $95 \%$ en een specificiteit van $100 \%$. In deze studie werd gekeken naar het percentage ten onrechte gediagnosticeerde kliernegatieve PCa-patiënten met PSMA PET/CT die na SKB alsnog klierpositief bleken te zijn. 


\section{Materiaal en methoden}

Van januari 2017 tot augustus 2018 werden alle patiënten met primair PCa en een negatieve PSMA PET/CT geïncludeerd. Een PSMA PET/CT werd preoperatief verricht bij PSA $>20 \mu \mathrm{g} / 1 \mathrm{en} /$ of Gleason-score $\geq 8$. Patiënten met een risico op LKM $>7 \%$ op het Briganti-nomogram kwamen in aanmerking voor SKB.

\section{Resultaten}

In totaal werden 106 patiënten met een negatieve PSMA $\mathrm{PET} / \mathrm{CT}$ geanalyseerd. SKB werd uitgevoerd bij 50 patiënten, ofwel voorafgaand aan uitwendige radiotherapie $(n=$ 25), ofwel gecombineerd met een uitgebreide lymfeklierdissectie (LKD) waarna robotgeassisteerde prostatectomie $(n=25)$ plaatsvond. Een mediaan van 6 (range 1-28) schildwachtklieren (SNs) per patiënt werd verwijderd. Vijftien van de 50 patiënten (30\%) bleken klierpositief met een mediaan van 2 (range 1-5) positieve SNs per patiënt. De mediane diameter van de LKM was 3,0 $\mathrm{mm}$ (range 1,0-8,0 mm). Van de 56 patiënten met negatieve PSMA PET/CT die alleen LKD ondergingen, waren minder patiënten klierpositief $(n=9)$ dan in de groep die SKB onderging $(16 \% v s$. $30 \% ; p=0,087)$. De mediane diameter van LKM bij deze 9 patiënten was 2,5 mm (range 0,1-6,0 mm).

\section{Conclusie}

Bij het primair gediagnosticeerd PCa zonder LKM op PSMA PET/CT blijkt alsnog 30\% van de patiënten klierpositief te zijn na SKB. PSMA PET/CT geeft een onderstadiëring van de lymfogene status en kan daarom een klierdissectie niet vervangen. SKB heeft een duidelijke meerwaarde in de stadiëring van het primair gediagnosticeerd PCa bij patiënten met een negatieve PSMA PET/CT.

\section{Verbetert de toevoeging van multiparametrische MRI aan de MSKCC en Partin-nomogrammen de voorspelling op lokaal gevorderde prostaatkanker?}

B.H.E. Jansen, J.A. Nieuwenhuijzen, D.E. Oprea-Lager, M.Y. Yska, A.P. Lont, R.J.A. van Moorselaar en A.N. Vis Amsterdam UMC, locatie VUmc; Maasstad Ziekenhuis, Rotterdam; Meander MC, Amersfoort

\section{Introductie}

Detectie van lokaal gevorderde prostaatkanker (T-stadium $3-4)$ is belangrijk voor het plannen van curatieve therapie. Multiparametrische MRI lijkt als individueel diagnosticum onvoldoende sensitief voor tumorstadiëring, maar is in combinatie met klinische parameters mogelijk wel van toegevoegde waarde. In deze studie evalueren we of mpMRI aan de MSKCC en Partin-nomogrammen toegevoegd kan worden, om de aanwezigheid van lokaal gevorderde prostaatkanker te voorspellen.

\section{Materiaal en methoden}

Preoperatieve mpMRI-uitkomsten van 430 robotgeassisteerde radicale prostatectomiepatiënten werden verzameld uit drie Nederlandse centra. De MSKCC en Partin-scores werden berekend, op basis van klinisch T-stadium, serumPSA Gleason-score en het aantal positieve biopten. Logistische regressieanalyse werd uitgevoerd op de combinatie van nomogramscores en mpMRI-uitkomsten. De diagnostische waarde van de gecombineerde modellen werd geevalueerd door middel van receiver operator characteristics (ROC) curves en de area under the curve (AUC). Zie figuur 8.1.

\section{Resultaten}

mpMRI is a significante voorspeller van gevorderde tumoren in multivariable analyse, zowel in combinatie met het MSKCC als het Partin-nomogram. De toevoeging van mpMRI verbeterde de AUC met $1 \%$ (MSKCC+mpMRI) en $4 \%$ (Partin+mpMRI) (niet significant).

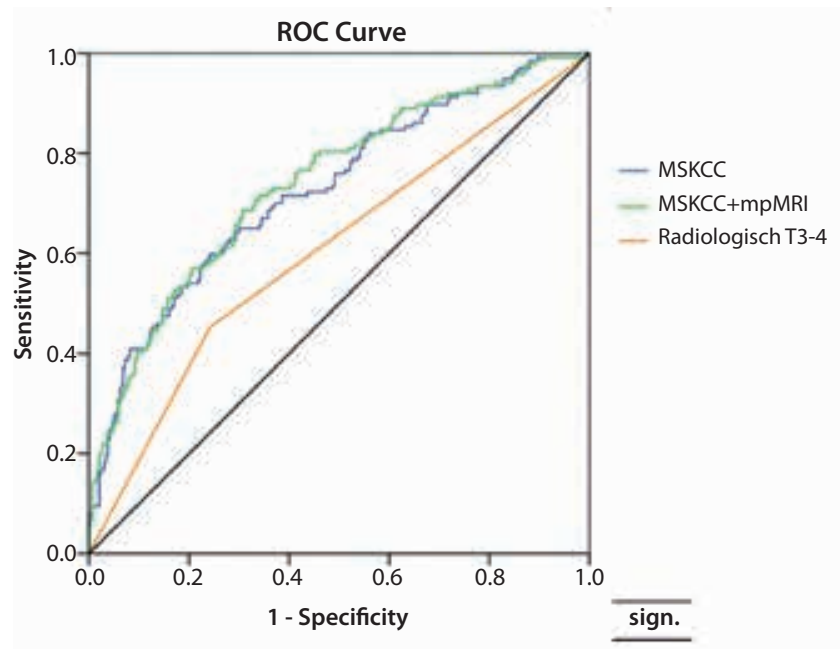

Figuur 8.1 Receiver operating charecteristics (ROC) curves en area under the curve (AUC) voor het MSKCC-nomogram, het gecombineerde MSKCC+mpMRI-model en de mpMRI-uitkomsten (radiologisch T3-4), ter voorspelling van lokaal gevorderde prostaatkanker (pathologisch T3-4).

\begin{tabular}{llll}
\hline AUC & $95 \%$-BI & & $p$ sign. \\
\hline 0,73 & 0,67 & 0,78 & $<0,01$ \\
\hline 0,74 & 0,69 & 0,79 & $<0,01$ \\
\hline 0,61 & 0,55 & 0,66 & $<0,01$ \\
\hline
\end{tabular}




\section{Conclusie}

In de huidige klinische praktijk verbetert de toevoeging van mpMRI aan de MSKCC en Partin-nomogrammen de risicoschatting op lokaal gevorderde prostaatkanker niet.

\section{Standaard pathologierevisie door een urogenitaal patholoog bij hoogrisicoblaaskanker: de invloed op het klinisch behandelplan}

\section{S.A. Berendsen, T. van Doeveren, G.J.L.H van Leenders} en J.L. Boormans

Erasmus MC, Rotterdam; LangeLand Ziekenhuis, Zoetermeer; Franciscus Gasthuis \& Vlietland, Rotterdam; Groene Hart Ziekenhuis, Gouda; IJsselland Ziekenhuis, Capelle aan den IJssel; Maasstad Ziekenhuis, Rotterdam; Het Van WeelBethesda Ziekenhuis, Spijkenisse; Adrz, Goes; Amphia, Breda

\section{Introductie}

De pathologische beoordeling van een transurethrale resectie (TUR) van een blaastumor is onderhevig aan inter- en intra-observationele variabiliteit. De keuze van behandeling hangt echter sterk af van deze beoordeling. Standaard pathologierevisie door een urogenitaal patholoog kan daarom van toegevoegde waarde zijn. In deze studie zijn de discrepanties tussen het initiële pathologieverslag en de revisie door een urogenitaal patholoog in een tertiair centrum voor patiënten met hoogrisicoblaaskanker (HRBK) onderzocht. Tevens werd geanalyseerd in welke mate de revisies tot veranderingen in het behandelplan hebben geleid.

\section{Materiaal en methoden}

Alle pathologierevisies van patiënten die tussen 2013 en 2016 waren verwezen vanuit tweedelijns ziekenhuizen uit de regio $(n=10)$ vanwege HRBK werden retrospectief verzameld. Het primaire eindpunt was het aantal discrepanties tussen het initiële verslag en het verslag na revisie. Het secundaire eindpunt was het percentage wijzigingen van het

Tabel 9.1 Overzicht van de belangrijkste discrepanties van pathologierevisie van preparaten van de transurethrale resectie van een blaastumor door de urogenitaal patholoog en in welke mate deze discrepanties leidde tot een wijziging in het behandelplan

\begin{tabular}{|c|c|c|c|}
\hline & $\begin{array}{l}\text { discordant }^{\mathrm{a}} / \\
\text { gewijzigd }^{\mathrm{b}}\end{array}$ & aantal (\%) & $\begin{array}{l}\text { aantal wijzigingen in } \\
\text { behandelplan }(\%)\end{array}$ \\
\hline \multirow[t]{3}{*}{ totaal aantal discrepanties } & & & $27 / 301(9,0 \%)$ \\
\hline & discordant & $148 / 301(49,2 \%)$ & $22(7,3 \%)$ \\
\hline & gewijzigd & $45(15,0 \%)$ & $5(1,7 \%)$ \\
\hline T-stadium & & $103(34,2 \%)$ & \\
\hline downstaging & discordant & $18 / 301(6,0 \%)$ & $8 / 301(2,7 \%)$ \\
\hline $\mathrm{T} 2 \rightarrow \mathrm{T} 1$ & discordant & $10(3,3 \%)$ & $5(1,7 \%)$ \\
\hline $\mathrm{T} 2+\mathrm{CIS} \rightarrow$ Tis & discordant & $1(0,3 \%)$ & $1(0,3 \%)$ \\
\hline $\mathrm{T} 1 \rightarrow \mathrm{Ta}$ & discordant & $1(0,3 \%)$ & 0 \\
\hline $\mathrm{T} 1 \rightarrow \mathrm{Tx}$ & discordant & $1(0,3 \%)$ & $1(0,3 \%)$ \\
\hline Tis $\rightarrow$ Tx & discordant & $1(0,3 \%)$ & $1(0,3 \%)$ \\
\hline Tis $\rightarrow$ Ta + CIS & gewijzigd & $2(0,7 \%)$ & 0 \\
\hline $\mathrm{T} 2 \rightarrow \mathrm{T} 1$ (divertikel) & gewijzigd & $2(0,7 \%)$ & 0 \\
\hline upstaging & discordant & $16 / 301(5,3 \%)$ & $6 / 301(2,0 \%)$ \\
\hline $\mathrm{T} 1 \rightarrow \mathrm{T} 2$ & discordant & $7(2,3 \%)$ & $4(1,3 \%)$ \\
\hline Tis + CIS $\rightarrow$ T $1+$ CIS & discordant & $1(0,3 \%)$ & 0 \\
\hline $\mathrm{Ta} \rightarrow \mathrm{T} 1$ & discordant & $3(1,0 \%)$ & 0 \\
\hline $\mathrm{Ta} \rightarrow \mathrm{Ta} / \mathrm{T} 1$ met mogelijke tangentiële aansnijding & discordant & $1(0,3 \%)$ & 0 \\
\hline $\mathrm{Tx} \rightarrow \mathrm{T} 2$ & discordant & $2(0,7 \%)$ & $1(0,3 \%)$ \\
\hline$\underline{\text { Tx } \rightarrow \text { Tis }}$ & discordant & $2(0,7 \%)$ & $1(0,3 \%)$ \\
\hline \multicolumn{4}{|l|}{ histologie } \\
\hline primaire histologie & discordant & $15 / 301(5,0 \%)$ & $8 / 301(2,7 \%)$ \\
\hline bijkomend carcinoma in situ (CIS) & gewijzigd & $68 / 218(31,2 \%)$ & $5 / 218(2,3 \%)$ \\
\hline
\end{tabular}

a Verandering na revisie in T-stadium of primaire histologie.

b Verandering na revisie in gradering (WHO 1973 en 2004), additionele histologie, carcinoma in situ of lymfovasculaire invasie. 
behandelplan. Discordante revisie was gedefinieerd als verandering in T-stadium of primaire histologie, en een gewijzigde revisie als een verandering in gradering (WHO 1973 en 2004), een verandering/toevoeging van additionele histologie, vaststellen van bijkomend carcinoma in situ of lymfovasculaire invasie.

\section{Resultaten}

In totaal werden 301 pathologierevisies geïncludeerd, waarvan er 45 (15,0\%) discordant en 103 (34,2\%) gewijzigd waren. De meest voorkomende discordantie betrof een aanpassing van het T-stadium; in 18 revisies was er sprake van downstaging en in 16 revisies van upstaging (tabel 9.1). Bij $27(9,0 \%)$ patiënten leidde de revisie tot een ander behandelplan. In de meeste gevallen betrof dit een wijziging in het wel (8/27) of niet (6/27) adviseren van een cystectomie.

\section{Conclusie}

Discordanties en wijzigingen bij revisies van het TUR-preparaat van patiënten met HRBK door een urogenitaal patholoog komen frequent voor. Bij 1 op de 11 patiënten leidde een aanpassing in de revisie tot een beleidswijziging. Standaard pathologierevisie vervult daarmee een belangrijke rol in het klinisch pad van patiënten met HRBK.

\section{Vroege continentie na urethrasparende techniek bij robot-geassisteerde laparoscopische prostatectomie}

\author{
K. Hulshof, M. Vermeer, J.H. Roelink, E.B. Cornel \\ en S.P. Stomps \\ ZGT Twente
}

\section{Introductie}

Incontinentie na RALP kan van grote invloed zijn op de kwaliteit van leven. Recente evaluatie van de Nederlandse RALPdatabase van 2017 toont een gemiddeld incontinentiepercentage omtrent $20 \%$ één jaar postoperatief. Schlomm et al. lieten in 2011 zien dat de lengte van de urethra is geassocieerd met vroeg continentieherstel. In deze studie wordt een eenvoudige urethrasparende techniek gepresenteerd resulterend in een grotere kans op vroege continentie.

\section{Materiaal en methoden}

In mei 2017 is gestart met de urethrasparende techniek (URALP), waarbij de urethra wordt vrijgeprepareerd tot aan de colliculus seminalis en aldaar doorgenomen. 72 patiënten met een minimale follow-up van 6 maanden, werden geïncludeerd en vergeleken met 300 patiënten die waren geopereerd middels de conventionele RALP tussen december 2014 en september 2017. Continentie werd gemeten 6 en 12 weken postoperatief door middel van de 24 uur pad-test.
Het gebruik van maximaal één pad/24 uur en $<10 \mathrm{~mL} /$ 24 uur verlies werd beschouwd als continent.

\section{Resultaten}

De baselinevariabelen waren vergelijkbaar tussen de groepen, op leeftijd na, die lager bleek in de URALP-groep dan in de RALP-groep, respectievelijk 64,0 en 65,4 jaar. Na 6 en 12 weken was respectievelijk $63,9 \%$ en $80,6 \%$ van de patiënten die URALP ondergingen continent versus $29,4 \%$ en $43,5 \%$ van de patiënten die conventionele RALP ondergingen $(p<0,001)$. De odds ratio (OR) na 6 weken was 4,1 (95\%-betrouwbaarheidsinterval $(\mathrm{BI})=2,4-7,2 ; p<0,001)$ en na 12 weken $5,3(95 \%-\mathrm{BI}=2,8-10,0 ; p<0,001)$, gecorrigeerd voor leeftijd. Het antal positieve snijvlakken bleek niet significant verschillend tussen beide groepen (URALP $27,8 \%$ en RALP $33,0 \%$ ), in overeenstemming met het landelijk gemiddelde van $28,9 \%$.

\section{Conclusie}

Urethrasparende RALP zorgt voor een significant grotere kans op vroege continentie 6 en 12 weken postoperatief, bij een vergelijkbaar aantal positieve snijvlakken in beide groepen.

\section{Blaassparende behandeling middels robot- geassisteerde laparoscopie en brachytherapie bij het solitaire spierinvasieve blaascarcinoom}

\author{
G.A.H.J. Smits, C.J. Wijburg, M.A.D. Haverkort, B. Oosterveld, \\ B.K. Kroon, P.C. Weijerman en E.M. van der Steen-Banasik \\ Rijnstate, Arnhem
}

\section{Introductie}

Blaassparende chirurgie gecombineerd met brachytherapie (BT) resulteert, bij de juiste inclusiecriteria, in gelijkwaardige oncologische uitkomsten in vergelijking met een cystectomie. Vanaf 2009 wordt in plaats van open chirurgie altijd laparoscopie toegepast (vanaf 2010 altijd robotgeassisteerd), is simultaneous pulse dose rate naar high dose rate (HDR) brachytherapie omgezet en is sedert 2016 bij een partiële cystectomie (PC) een dosis-de-escalatie uitgevoerd.

\section{Materiaal en methoden}

Laparoscopie is toegepast bij 119 opeenvolgende patiënten na informed consent. De EBRT startte acht weken na TUR van een solitaire tumor cT1-3aN0 (MRI,CT) $<5 \mathrm{~cm},(2 \%$ rec pT1, $98 \% \geq \mathrm{pT} 1$ ) grade 2-3, geen CIS: 40 Gy in 20 fracties op de blaas en de regionale klieren. Chirurgie vond één week na EBRT plaats. PC met marges van 2-3 mm (38) indien sprake was van: $>1 \mathrm{~cm}$ residuele tumor $(n=23)$, tumor in een divertikel $(n=5)$, urachus $(n=5)$ of betrokkenheid van distale ureter $(n=5 ; 2 \mathrm{x}$ nefro-ureterectomie, $3 \mathrm{x}$ ureterreïmplantatie). Brachytherapie bestond uit after- 
loader met Ir-192-bron, activiteit 37-13 GBq. HDR-schema: 25 Gy, 10 fracties met een interval $\geq 4$ h, 3 fr/dag. PC: de-escalatie van 10 x 2,5 Gy in 3,5 d (eerste 18 casus) naar 17,5 Gy $7 \mathrm{fr} / 2,5 \mathrm{~d}$.

\section{Resultaten}

Er werden vier patiënten geëxcludeerd (3 out of protocol, 1 behandeling niet afgemaakt). De mediane opname bedroeg 5,0 d, bij PC met dosis-de-escalatie 4,0 d. Er trad toxiciteit op bij 16 patiënten, (CTCAEv4): (a) acute toxicatie G3-4: delier $(n=3)$, ileus $(n=1)$ en longembolie $(n=1)$; (b) late toxicatie G2-3: hematurie $(n=3)$, urgency $(n=3)$, lymfoedeem $(n=2)$, necrose van de blaaswand $(n=1)$, rec cystitis $(n=1)$, hydronephroses $(n=1)$.

FU totale groep: 2,9 jaar (1 mnd - 8,8 jr); 2 jaar lokale controle $82 \%, 2$ jaar ziektevrije overleving $89 \%$. FU PC-groep: 2,5 jaar (0,3-6,7 jr); géén in field lokaal recidief, 97\% ziektevrije overleving. Definitief PA PC-preparaat; 49\% pT0, 11\% pT1 en $40 \%{ }^{3}$ pT 2 .

\section{Conclusies}

Deze gecombineerd radiotherapeutische en robotgeassisteerde behandeling met snel operatief herstel en weinig toxiciteit, resulteert in zeer goede oncologische uitkomsten en is een valide alternatief voor een cystectomie voor deze categorie spierinvasieve blaastumoren. De uitstekende lokale controle rechtvaardigt de HDR de-escalatie bij een partiële cystectomie.

\section{Follow-up van patiënten na radicale prostatectomie met sentinelnode-procedure: analyse van biochemische recidieven met PSMA-PET/CT}

O.R. Brouwer, E. Wit, P.J. van Leeuwen, F.W.B. van Leeuwen en H.G. van der Poel

Antoni van Leeuwenhoek, Amsterdam

\section{Introductie}

De robotgeassisteerde radicale prostatectomie (RARP) met extended pelviene lymfeklierdissectie (ePLKD) is een van de toegepaste behandelingen voor patiënten met een matig tot hoog risico prostaatcarcinoom (PCa). De sentinelnode (SN) procedure (SNP) kan de diagnostische nauwkeurigheid van een ePLKD vergroten. Daarnaast is aangetoond dat toevoeging van een SNP kan leiden tot een langere biochemisch recidief(BCR)vrije overleving.

\section{Materiaal en methoden}

Bij patiënten die geïncludeerd werden in een prospectief gerandomiseerde fase-II-studie naar de invloed van SN-tracertoediening ten aanzien van tumorlocatie, werd gekeken naar

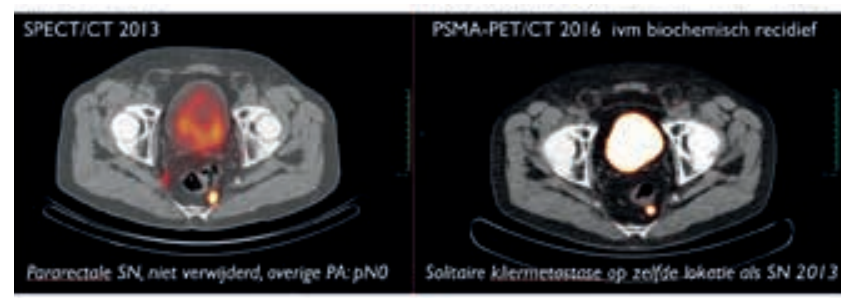

Figuur 12.1

BCR-overleving. Alle patiënten ondergingen een RARP met SNP, gevolgd door ePLKD. Ter verdere validatie en optimalisatie van de SNP voor PCa hebben wij de follow-updata en patiënten met BCR nader geanalyseerd.

\section{Resultaten}

Tussen 2013 en 2016 werden 113 patiënten geïncludeerd. 37 patiënten hadden één of meer tumorpositieve lymfeklieren (33\%). Bij 35 van deze patiënten was de SN ook positief (95\%, fout-negatief ratio 5\%). De gemiddelde follow-upduur na de operatie was 29,3 maanden (mediaan 27,5). Een BCR werd vastgesteld bij 29 patiënten (26\%). Bij 25/29 $(86 \%)$ werd aanvullende beeldvorming verricht (PSMAPET $n=20$; choline-PET $n=4$; nano MRI $n=1$ ). $15 / 25$ patiënten hadden hierop aanwijzingen voor een klierrecidief (60\%). Bij de meeste patiënten was er (ook) sprake van een regionaal klierrecidief (87\%). 5/15 patiënten waren bij $\mathrm{SN}+$ ePLND pN0 gestadieerd (33\%). Hiervan had één patiënt een non-visualisatie op SPECT/CT, één had ook afstandmetastasen, en drie patiënten hadden een recidief op PSMA-PET/ CT op dezelfde locatie als de SN destijds op SPECT/CT (deze was dus waarschijnlijk peroperatief gemist of op een bijzondere locatie gelegen, figuur 12.1).

\section{Conclusies}

Bij de pN0-patiënten met BCR en een klierrecidief op PSMA$\mathrm{PET} / \mathrm{CT}$ was er in $80 \%$ van de gevallen sprake van een technisch niet-geslaagde SNP of een SN die niet geëxcideerd was. Dit ondersteunt de accuratesse van SNP voor klierstadiëring bij PCa-patiënten en het potentiële belang van het verwijderen van SNs buiten het ePLKD-gebied.

\section{Voorspelling van extracapsulaire extensie tijdens radicale prostatectomie. Een valide instrument om je chirurgische plan op aan te passen?}

S.E.A.G. Grootscholten, P.J. van Leeuwen, A.N. Vis, T. Roeleveld, E.M.K. Wit, J.A. Nieuwenhuijzen en H.G. van der Poel Amsterdam UMC, locatie VUmc, Amsterdam; Prostaatkankernetwerk, Amsterdam 


\section{Introductie}

De betrouwbaarheid van de multiparametrische MRI voor de voorspelling van extracapsulaire extensie (ECE) ten tijde van radicale prostatectomie (RP) staat ter discussie. Echter, een goede voorspelling van de kans op ECE is van invloed op de keuze voor zenuwsparende chirurgie en de kans op een positief snijvlak. Doel van deze studie is het maken van een risicowijzer die inzicht geeft in de kans op ECE op basis van preoperatieve klinische patiëntkarakteristieken en de toegevoegde waarde van een preoperatieve MRI.

\section{Materiaal en methode}

Inclusie van 948 mannen met klinisch stadium T1c-T3-prostaatkanker die waren behandeld middels RP. Kandidaat-klinische variabelen die zijn geassocieerd met ECE waren: de leeftijd van de patiënt, het PSA, het klinisch T-stadium, prostaatvolume, de Gleason-score in een biopt, het percentage positieve biopten en het T-stadium op de MRI. Receiver operating characteristic (ROC) analyses werden uitgevoerd om de voorspellende waarde van de individuele en de combinatie van de variabele vast te stellen. Er is een nomogram gemaakt om de patiëntspecifieke kans op ECE te berekenen.

\section{Resultaten}

In totaal had 37,4\% van de patiënten ECE. De areas under the ROC curves (AUC) voor de individuele variabele voor de voorspelling van ECE was 0,55 voor leeftijd, 0,61 voor PSA, 0,63 voor cT-stadium, 0,64 voor ISUP-score, 0,65 voor het percentage positieve biopten, 0,55 voor prostaatvolume en 0,73 voor MRI. De AUC voor het basismodel (leeftijd, PSA, cT-stadium, Gleason-score, precentage positieve biopten en prostaatvolume) was $0,73(95 \%$-BI $=0,69-0,76)$. Na toevoeging van de preoperatieve MRI steeg de nauwkeurigheid sig-

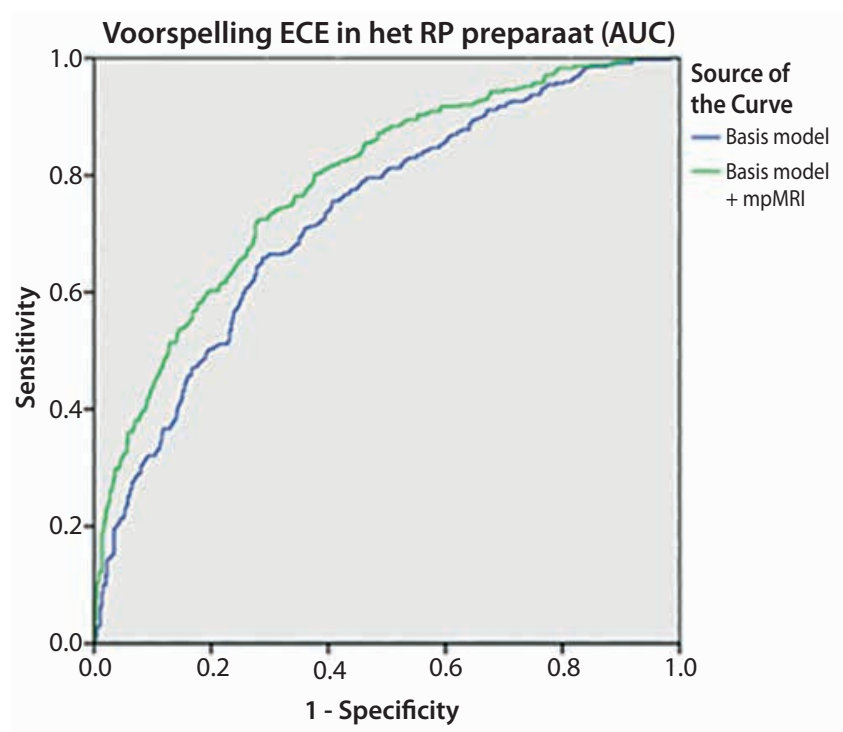

Figuur 13.1 nificant naar $0,79(95 \%-\mathrm{BI}=0,76-0,82)$. Het intern gevalideerde nomogram had een goede kalibratie en discriminatiewaarde.

\section{Conclusie}

Preoperatieve klinische kenmerken kunnen gebruikt worden voor het bepalen van de kans op ECE in RP-preparaten. De predictieve waarde van het basismodel stijgt significant na toevoeging van het klinisch stadium op basis van MRI.

\section{Robotgeassisteerde laparoscopische enucleatie van de prostaat (RALEP), een goed alternatief voor de open prostatectomie bij patiënten met forse BPH}

\author{
A. van Uitert, G.A.H.J. Smits, P.C. Weijerman en C.J. Wijburg \\ Rijnstate, Arnhem
}

\section{Introductie}

De meest voorkomende oorzaak voor LUTS bij mannen is benigne prostaathyperplasie (BPH). De gouden standaard voor prostaten $>100 \mathrm{~mL}$ is in Nederland de open prostatectomie, hoewel technieken zoals Green Light Laser, Holmium Laser Enucleatie (HoLEP) en minimaal invasieve operaties in opkomst zijn. Gezien de ruime ervaring met robot-prostatectomieën bij prostaatkanker werd in 2014 de robotgeassisteerde laparoscopische enucleatie van de prostaat (RALEP) in ons centrum geïntroduceerd als alternatief voor de klassieke open procedure. In deze studie beschrijven wij het grootste Nederlandse cohort van deze techniek.

\section{Methode}

Patiënten kwamen in aanmerking voor RALEP bij echografisch geschatte $\mathrm{BPH}^{3} 100 \mathrm{cc}$ met LUTS. Middels retrospectief onderzoek zijn de pre-, peri- en postoperatieve gegevens van patiënten verzameld en geanalyseerd. Statistische analyse van de data werd verricht middels SPSS.

\section{Resultaten}

Tussen september 2014 en maart 2018 werden 80 patiënten geopereerd van wie 52 patiënten katheterafhankelijk waren. De gemiddelde leeftijd was 70 jaar en het mediane preoperatieve prostaatvolume was $132 \mathrm{cc}$. De gemiddelde IPSS bij patiënten zonder katheter was 22/4. De mediane operatieduur was 134 minuten met een mediaan bloedverlies van $250 \mathrm{cc}$; vijf patiënten kregen een bloedtransfusie. Na aanpassing van het postoperatieve protocol in oktober 2015 was de mediane opnameduur vijf dagen met een mediane katheterduur van drie dagen. 27 patiënten hadden een Clavien 1-2-complicatie (urineweginfectie, hematurie), twee patiënten een Clavien-3-complicatie en twee patiënten een Clavien4-complicatie. Vijf patiënten ontwikkelden een passagère postoperatieve retentie. De gemiddelde flow-snelheid 
postoperatief was $25 \mathrm{~mL} / \mathrm{sec}$, het mediane residu $33 \mathrm{cc}$ (na 6-12 weken). De gemiddelde postoperatieve IPSS was 7/1.

\section{Conclusie}

RALEP is een effectieve minimaal invasieve techniek bij patiënten met LUTS op basis van BPH $>100 \mathrm{cc}$. In vergelijking met gepubliceerde data lijken de uitkomsten superieur aan de open procedure en vergelijkbaar met HoLEP. Prospectief vergelijkende studies zijn van belang om de plaats van de verschillende technieken verder te definiëren.

\section{Resultaten van klierdissectie bij open, laparoscopische en robotgeassisteerde prostatectomie in Nederland}

O.R. Brouwer, T.A. Roeleveld, G. Commelin, E.M.K. Wit,

P.J. Leeuwen en H.G. van der Poel

Antoni van Leeuwenhoek, Amsterdam

\section{Introductie}

Sinds 10 jaar worden op www.nvukwaliteit.nl de resultaten van de prostatectomie in Nederland geregistreerd. De resultaten van drie centra met verschillende typen prostatectomie zijn met elkaar vergeleken om een indruk te krijgen van de casemix, en om als benchmark te fungeren voor verdere samenwerking.

\section{Materiaal en methoden}

$\mathrm{Na}$ toestemming van de deelnemende klinieken werden de data van de NVU-database-prostatectomie gedownload en geanalyseerd in SPSS V22. De baseline kenmerken en klinische gegevens werden in kaart gebracht.

\section{Resultaten}

In de afgelopen 10 jaar werden 2.711 prostatectomieën vanuit de drie klinieken geregistreerd. Het mediane initiële PSA was $8 \mathrm{ng} / \mathrm{ml}$ voor de kliniek met robotingrepen, $15 \mathrm{ng} / \mathrm{ml}$ voor de kliniek met open ingrepen en $9 \mathrm{ng} / \mathrm{ml}$ voor de kliniek met laparoscopische ingrepen $(p<0,01)$. Het percentage pT3-4-tumoren was $31 \%, 44 \%$ en $31 \%$ respectievelijk. Een

Tabel 15.1

\begin{tabular}{llll}
\hline percentage patiënten & $\begin{array}{l}\text { robot- } \\
\text { geassis- } \\
\text { teerd }\end{array}$ & $\begin{array}{l}\text { laporos- } \\
\text { copisch }\end{array}$ \\
\hline met klierdissectie & $55 \%$ & $54 \%$ & $46 \%$ \\
met pN1 bij klierdissectie & $19 \%$ & $26 \%$ & $6 \%$ \\
mediaan aantal verwijderde klieren & 13 & 20 & 7 \\
met klierdissectie en 1 positieve klier & $10 \%$ & $12 \%$ & $11 \%$ \\
met pN1 en 1 positieve klier & $52 \%$ & $37 \%$ & $75 \%$ \\
\hline
\end{tabular}

klierdissectie werd uitgevoerd bij ongeveer de helft van de patiënten in alle klinieken, waarbij mediaan 7-20 klieren werden verwijderd. Het percentage patiënten met positieve klieren varieerde van $6-26 \%$. Een laag mediaan aantal verwijderde klieren was gecorreleerd met een lager percentage patiënten met positieve klieren, maar niet met een verschil in percentage patiënten met maar 1 positieve klier (tabel 15.1).

\section{Conclusie}

De klinieken behandelen heterogene groepen patiënten waarbij in de kliniek met open ingrepen meer pT3-tumoren werden gevonden. Het aantal geanalyseerde klieren correleerde met de kans op positieve klieren, maar niet met het percentage patiënten met één positieve klier, wat suggereert dat aspecten als uitgebreidheid van de resectie en pathologieanalyse, maar niet de tumorkarakteristieken een verklaring vormen voor de gevonden verschillen tussen klinieken. Standaardisatie van deze aspecten is gewenst.

\section{Contaminatie van flexibele ureterorenoscopen ondanks desinfectie}

J.D. Legemate, G.M. Kamphuis, J.E. Freund, J. Baard, H.W. Oussoren, I.J.B. Spijkerman en J.J.M.C.H. de la Rosette Amsterdam UMC, locatie AMC; Universiteit van Amsterdam, Amsterdam; Istanbul Medipol University, Istanbul, Turkije en Amsterdam UMC, locatie AMC; Universiteit van Amsterdam, Amsterdam

\section{Introductie}

Inadequate desinfectie van herbruikbare ureteroscopen (USc) kan leiden tot contaminatie en besmetting van patiënten. Tot op heden is er weinig bekend over de effectiviteit van USc-desinfectie. Deze studie onderzocht de frequentie van microbiële contaminatie na USc-desinfectie en de kans op toename van contaminatie met cumulatief gebruik van de USc.

\section{Methode}

Gedurende twee jaar werden er pre- en postoperatieve microbiële kweken van de schacht en het werkkanaal van 20 nieuwe USc's genomen. Er werd op bacteriën en gisten gekweekt. Een positieve kweek was gedefinieerd als $\geq 30 \mathrm{kve} / \mathrm{mL}$ aan huidflora of $\geq 10 \mathrm{kve} / \mathrm{mL}$ aan uropathogenen. Na gebruik werden de USc met perazijnzuur gedesinfecteerd en handmatig verpakt volgens bestaand protocol. Postoperatief werd nagegaan of patiënten symptomen van een urineweginfectie ontwikkelden. De associatie tussen USc-contaminatie en cumulatief USc-gebruik werd getest middels een generalized estimating equations model. Het cumulatief gebruik van USc werd geanalyseerd middels de volgende factoren: aantal procedures, ureteroscopietijd, laserenergie en het aantal passages van hulpmiddelen door het werkkanaal. 
cec bohn

9) stafleu

van loghum

bohn

stafleu

van loghum

bohn

stafleu

- van loghum
CCS bohn
8 stafleu
L van loghum

cec bohn

stafleu

cL van loghum

CCe bohn

9) stafleu

bohn

3 stafleu

van loghum

cCehn bohn

85 stafleu

C. van loghum

cec bohn

S) stafleu

van loghum

bohn

stafleu

van loghum

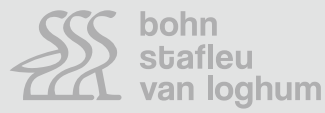

CC bohn

stafleu

van loghum

-) bohn

van loghum

cCehn bohn

stafleu

van loghum

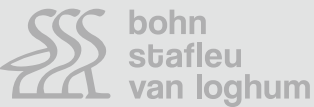

¿S $\begin{aligned} & \text { bohn } \\ & \text { stafleu } \\ & \text { van loghum }\end{aligned}$

SS bohn

van loghum $\int S \begin{aligned} & \text { bohn } \\ & \text { stafleu }\end{aligned}$

van loghum

CSe bohn

van loghum
Stafleu

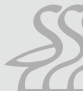

SS bohn

van loghum

CS bohn

3 stafleu

van loghum

CSe bohn

3 stafleu

van loghum bohn
stafleu
van loghum
bohn
stafleu
van loghum

bohn
stafleu
van loghum
bohn
stafleu
van loghum

bohn
stafleu
van loghum
bohn
stafleu
van loghum

bohn
stafleu
van loghum
bohn
stafleu
van loghum

stafleu

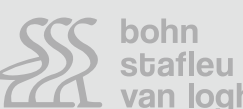

bohn
stafleu
van loghum
bohn
stafleu
van loghum

C. van loghum van loghum

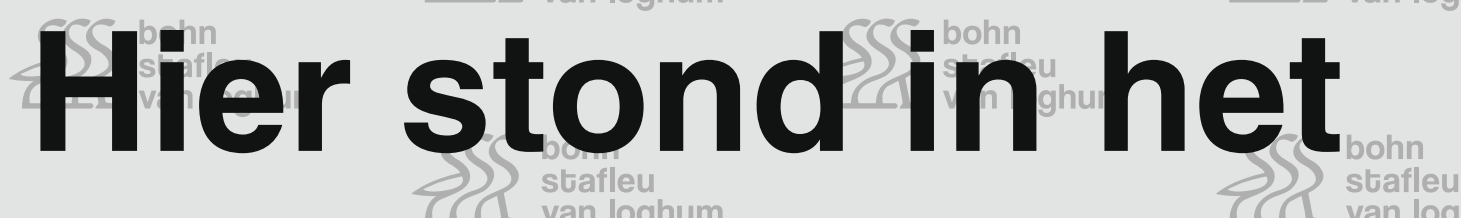

Strafleu 3 stafleu



$\iint \begin{aligned} & \text { bohn } \\ & \text { stafleu }\end{aligned}$

1. van loghum

CCe bohn

strafleu

van loghum

bohn
stafleu
van loghum
bohn
stafleu
van loghum

bohn
stafleu
van loghum
bohn
stafleu
van loghum

CCS bohn

Stafleu

- van loghum

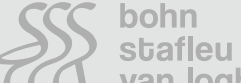

van loghum

CC bohn

8 stafleu

(1) van loghum

$\iint \begin{aligned} & \text { bohn } \\ & \text { stafleu } \\ & \text { van loghu }\end{aligned}$

van loghum

cCe bohn

3 stafleu

L van loghum

CCS bohn

8tufleu

C. van loghum

SCS bohn

van loghum

CCS bohn

8) stafleu

CSe bohn

stafleu

CL van loghum 
cec bohn

9) stafleu

van loghum

bohn

stafleu

van loghum

bohn

stafleu

- van loghum
CCS bohn
8 stafleu
L van loghum

cec bohn

stafleu

cL van loghum

CCe bohn

9) stafleu

bohn

3 stafleu

van loghum

cCehn bohn

85 stafleu

C. van loghum

cec bohn

S) stafleu

van loghum

bohn

stafleu

van loghum

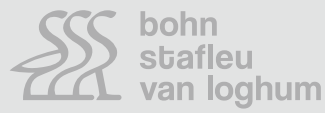

CC bohn

stafleu

van loghum

-) bohn

van loghum

cCehn bohn

stafleu

van loghum

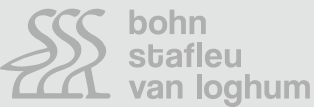

¿S $\begin{aligned} & \text { bohn } \\ & \text { stafleu } \\ & \text { van loghum }\end{aligned}$

SS bohn

van loghum $\int S \begin{aligned} & \text { bohn } \\ & \text { stafleu }\end{aligned}$

van loghum

CSe bohn

van loghum
Stafleu

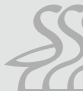

SS bohn

van loghum

CS bohn

3 stafleu

van loghum

CSe bohn

3 stafleu

van loghum bohn
stafleu
van loghum
bohn
stafleu
van loghum

bohn
stafleu
van loghum
bohn
stafleu
van loghum

bohn
stafleu
van loghum
bohn
stafleu
van loghum

bohn
stafleu
van loghum
bohn
stafleu
van loghum

stafleu

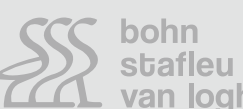

bohn
stafleu
van loghum
bohn
stafleu
van loghum

C. van loghum van loghum

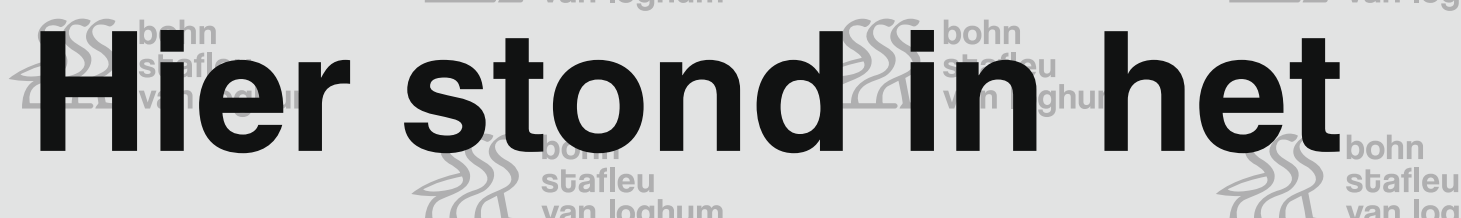

Strafleu 3 stafleu

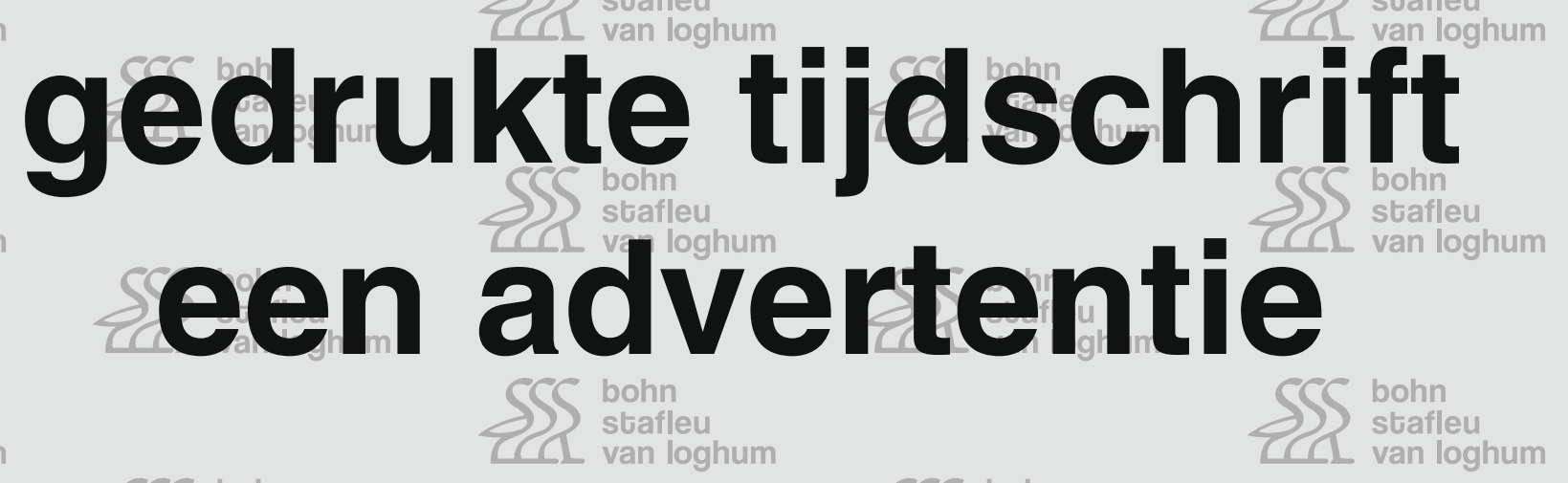

$\iint \begin{aligned} & \text { bohn } \\ & \text { stafleu }\end{aligned}$

1. van loghum

CCe bohn

strafleu

van loghum

bohn
stafleu
van loghum
bohn
stafleu
van loghum

bohn
stafleu
van loghum
bohn
stafleu
van loghum

CCS bohn

Stafleu

- van loghum

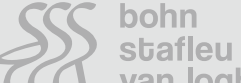

van loghum

CC bohn

8 stafleu

(1) van loghum

$\iint \begin{aligned} & \text { bohn } \\ & \text { stafleu } \\ & \text { van loghu }\end{aligned}$

van loghum

cCe bohn

3 stafleu

L van loghum

CCS bohn

8tufleu

C. van loghum

SCS bohn

van loghum

CCS bohn

8) stafleu

CSe bohn

stafleu

CL van loghum 
cec bohn

9) stafleu

van loghum

bohn

stafleu

van loghum

bohn

stafleu

- van loghum
CCS bohn
8 stafleu
L van loghum

cec bohn

stafleu

cL van loghum

CCe bohn

9) stafleu

bohn

3 stafleu

van loghum

cCehn bohn

85 stafleu

C. van loghum

cec bohn

S) stafleu

van loghum

bohn

stafleu

van loghum

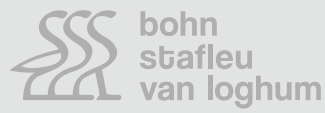

CC bohn

stafleu

van loghum

-) bohn

van loghum

cCehn bohn

stafleu

van loghum

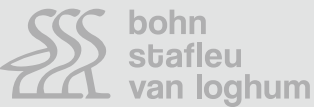

¿S $\begin{aligned} & \text { bohn } \\ & \text { stafleu } \\ & \text { van loghum }\end{aligned}$

SS bohn

van loghum $\int S \begin{aligned} & \text { bohn } \\ & \text { stafleu }\end{aligned}$

van loghum

CSe bohn

van loghum
Stafleu

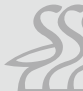

SS bohn

van loghum

CS bohn

3 stafleu

van loghum

CSe bohn

3 stafleu

van loghum bohn
stafleu
van loghum
bohn
stafleu
van loghum

bohn
stafleu
van loghum
bohn
stafleu
van loghum

bohn
stafleu
van loghum
bohn
stafleu
van loghum

bohn
stafleu
van loghum
bohn
stafleu
van loghum

stafleu

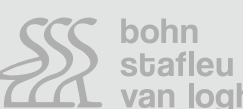

bohn
stafleu
van loghum
bohn
stafleu
van loghum

C. van loghum van loghum

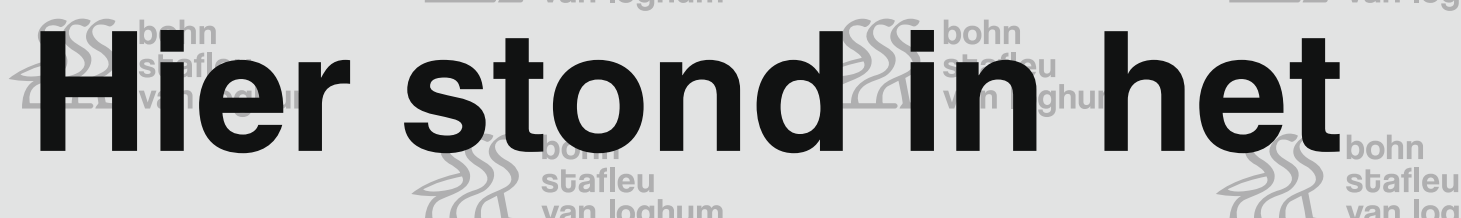

Strafleu 3 stafleu

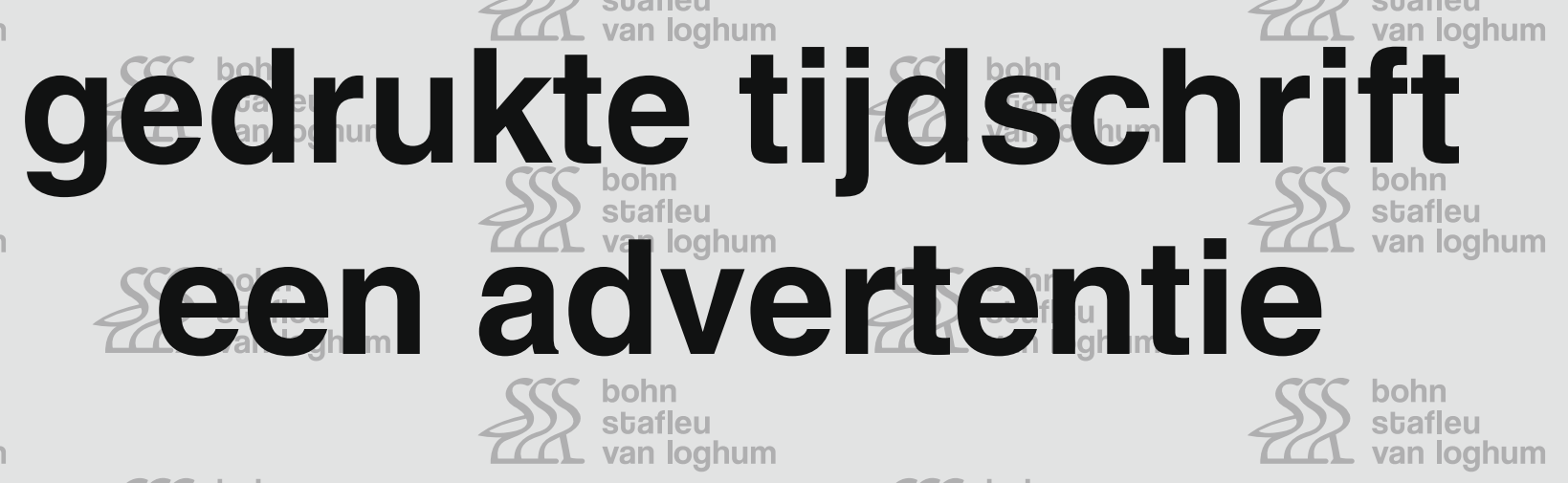

$\iint \begin{aligned} & \text { bohn } \\ & \text { stafleu }\end{aligned}$

1. van loghum

CCe bohn

strafleu

van loghum

bohn
stafleu
van loghum
bohn
stafleu
van loghum

bohn
stafleu
van loghum
bohn
stafleu
van loghum

CCS bohn

Stafleu

- van loghum

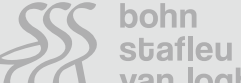

van loghum

CC bohn

8 stafleu

(1) van loghum

$\iint \begin{aligned} & \text { bohn } \\ & \text { stafleu } \\ & \text { van loghu }\end{aligned}$

van loghum

cCe bohn

3 stafleu

L van loghum

CCS bohn

8tufleu

C. van loghum

SCS bohn

van loghum

CCS bohn

8) stafleu

CSe bohn

stafleu

CL van loghum 
cec bohn

9) stafleu

van loghum

bohn

stafleu

van loghum

bohn

stafleu

- van loghum
CCS bohn
8 stafleu
L van loghum

cec bohn

stafleu

cL van loghum

CCe bohn

9) stafleu

bohn

3 stafleu

van loghum

cCehn bohn

85 stafleu

C. van loghum

cec bohn

S) stafleu

van loghum

bohn

stafleu

van loghum

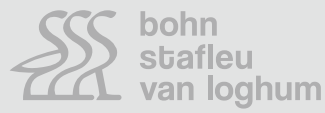

CC bohn

stafleu

van loghum

-) bohn

van loghum

cCehn bohn

stafleu

van loghum

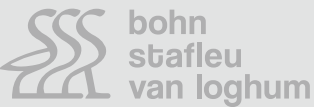

¿S $\begin{aligned} & \text { bohn } \\ & \text { stafleu } \\ & \text { van loghum }\end{aligned}$

SS bohn

van loghum $\int S \begin{aligned} & \text { bohn } \\ & \text { stafleu }\end{aligned}$

van loghum

CSe bohn

van loghum
Stafleu

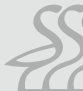

SS bohn

van loghum

CS bohn

3 stafleu

van loghum

CSe bohn

3 stafleu

van loghum bohn
stafleu
van loghum
bohn
stafleu
van loghum

bohn
stafleu
van loghum
bohn
stafleu
van loghum

bohn
stafleu
van loghum
bohn
stafleu
van loghum

bohn
stafleu
van loghum
bohn
stafleu
van loghum

stafleu

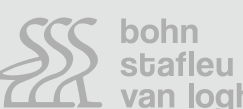

bohn
stafleu
van loghum
bohn
stafleu
van loghum

C. van loghum van loghum

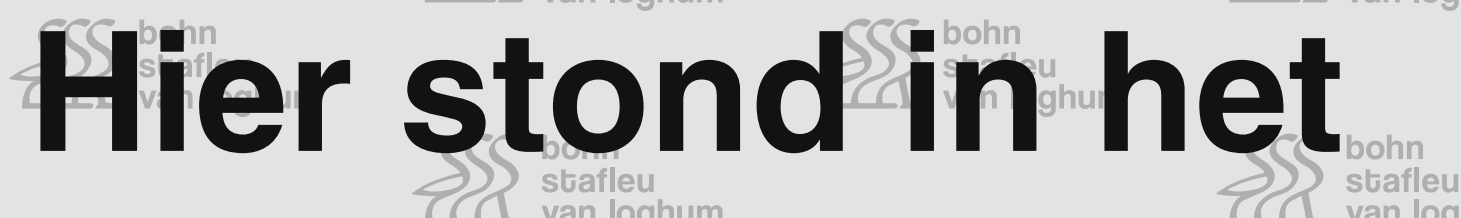

Strafleu 3 stafleu

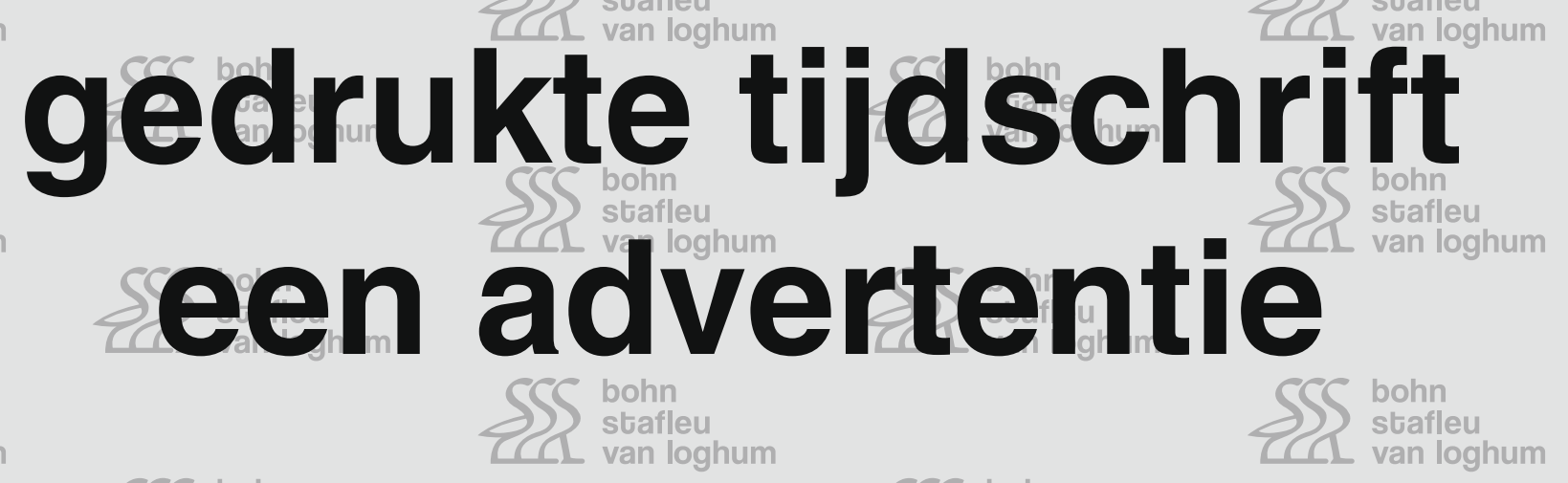

$\iint \begin{aligned} & \text { bohn } \\ & \text { stafleu }\end{aligned}$

1. van loghum

CCe bohn

strafleu

van loghum

bohn
stafleu
van loghum
bohn
stafleu
van loghum

bohn
stafleu
van loghum
bohn
stafleu
van loghum

CCS bohn

Stafleu

- van loghum

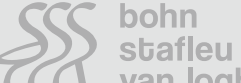

van loghum

CC bohn

8 stafleu

(1) van loghum

$\iint \begin{aligned} & \text { bohn } \\ & \text { stafleu } \\ & \text { van loghu }\end{aligned}$

van loghum

cCe bohn

3 stafleu

L van loghum

CCS bohn

8tufleu

C. van loghum

SCS bohn

van loghum

CCS bohn

8) stafleu

CSe bohn

stafleu

CL van loghum 
Tabel 16.1 Specificatie van de procedures waarin de kweken uropathogenen lieten zien

\begin{tabular}{llll}
\hline USc-type en -ID & $\begin{array}{l}\text { cumulatief } \\
\text { procedurenummer }\end{array}$ & $\begin{array}{l}\text { preoperatief kweekresultaat } \\
\text { USc-tip }\end{array}$ & $\begin{array}{l}\text { preoperatief kweekresultaat } \\
\text { USc-werkkanaal }\end{array}$ \\
\hline OL URF V2-1 & 18 & E. coli $(120 \mathrm{kve} / \mathrm{mL})$ & huidflora $(70 \mathrm{kve} / \mathrm{mL})$ \\
\hline KS FLEX XC-2 & 19 & E. coli $(90 \mathrm{kve} / \mathrm{mL})$ & E. coli $(10 \mathrm{kve} / \mathrm{mL})$ \\
\hline KS FLEX X2-1 & 18 & S. aureus $(10 \mathrm{kve} / \mathrm{mL})$ & negatief \\
\hline OL URF V2-3 & 6 & E. coli $(18 \mathrm{kve} / \mathrm{mL})$ & E. coli $(10 \mathrm{kve} / \mathrm{mL})$ \\
\hline KS FLEX XC-4 & 5 & E. faecalis $(20 \mathrm{kve} / \mathrm{mL})$ & E. coli $(20 \mathrm{kve} / \mathrm{mL})$, \\
\hline KS FLEX XC-1 & 65 & E. coli $(160 \mathrm{kve} / \mathrm{mL})$ & E. coli $(10 \mathrm{kve} / \mathrm{mL})$ \\
\hline KS FLEX XC-4 & 22 & negatief & gist $(10 \mathrm{kve} / \mathrm{mL})$ \\
\hline KS FLEX XC-10 & 3 & negatief & S. aureus $(10 \mathrm{kve} / \mathrm{mL})$ \\
\hline KS FLEX XC-10 & 9 & S. aureus $(760 \mathrm{kve} / \mathrm{mL})$ & negatief
\end{tabular}

E. coli $=$ Escherichia coli, E. faecalis = Enterococcus faecalis, kve kolonie vormende eenheden, KS Karl Storz, OL Olympus, S. aureus = Staphylococcus aureus .

\section{Resultaten}

In 47 van de 389 (12,1\%) URS-procedures waren de preoperatieve kweken positief. In negen procedures $(2,3 \%)$ werden uropathogenen en in 38 procedures $(9,8 \%)$ werd huidflora gekweekt (tabel 16.1). In één geval liet de postoperatieve kweek hetzelfde type bacterie ( $S$. aureus) zien als de daaropvolgende preoperatieve kweek van dezelfde USc. Geen van de vier factoren voor cumulatief USc-gebruik was geassocieerd met een grotere kans op een positieve preoperatieve kweek. In de negen procedures waarbij in de preoperatieve USc-kweek uropathogenen werden gevonden, ontwikkelde de patiënten geen symptomen van een urineweginfecties.

\section{Conclusies}

Ondanks desinfectie is een deel van de ureteroscopen gecontamineerd met microbiële organismen, waaronder ook uropathogenen. De kans op USc-contaminatie na desinfectie neemt niet toe naarmate de USc vaker wordt gebruikt. De klinische implicatie van deze bevindingen ten aanzien van de patiëntveiligheid verdient verdere aandacht.

\section{Voorspelling oncologische uitkomst na salvageradiotherapie voor recidief prostaatkanker na radicale prostatectomie}

B. de Ruiter, P.J. van Leeuwen, J.A. Nieuwenhuijzen, T. Roeleveld, E.M.K. Wit, A.N. Vis en H.G. van der Poel Amsterdam UMC, locatie VUmc; Antoni van Leeuwenhoek, Amsterdam; Prostaatkankernetwerk, Amsterdam

\section{Introductie}

Salvageradiotherapie is een behandelingsoptie voor prostaatkankerpatiënten met een biochemisch recidief na radicale prostatectomie (RP). Doel van deze studie is het identificeren van risicofactoren voor de kans op succesvolle salvageradiotherapie in het tijdperk van de ultrasensitieve PSA-test.

\section{Materiaal en methoden}

Inclusie van 460 patiënten, status na RP ( $\mathrm{pN0} / \mathrm{x}$ ), met een PSA-stijging na RP (PSA $=0,05-1,0 \mathrm{ng} / \mathrm{ml}$ ), die waren behandeld met salvageradiotherapie (70 Gy) op de prostaatfossa, zonder hormonale therapie. De volgende data werden verzameld: leeftijd, tijd vanaf $R P$, initiële pathologie (pT-stadium, Gleason-score, chirurgische snijranden), mate van zenuwsparende chirurgie (FP-score) en het PSA ten tijde van de salvageradiotherapie. Oncologische studie-uitkomst is biochemische progressie (PSA $\geq 0,5 \mathrm{ng} / \mathrm{ml}$ ) binnen twee jaar na salvageradiotherapie. Er werden logistische regressiemodellen gebouwd en getest met areas under the curve (AUC's) analyse.

\section{Resultaten}

De mediane leeftijd van de patiënt, het PSA tijdens salvageradiotherapie en de tijd sinds initiële behandeling is respectievelijk 68 jaar, $0,25 \mathrm{ng} / \mathrm{ml}$ en 13 maanden. $\mathrm{Na} 2$ jaar had $33,7 \%$ een PSA $\geq 0,5 \mathrm{ng} / \mathrm{ml}$. In multivariate analyse zijn een relatief lager PSA ten tijde van salvageradiotherapie, een relatief lager pT-stadium, een positief chirurgische snijvlak en een hogere mate van zenuwsparende chirurgie significant gecorreleerd aan een betere respons op salvageradiotherapie. De AUC voor het model is $0,79(95 \%-\mathrm{BI}=0,73-0,84)$. Zie tabel 17.1. 
Tabel 17.1 Multivariate analyse van biochemische progressie na salvageradiotherapie

\begin{tabular}{lll}
\hline & exp. (B) (95\%-BI) & $p$ \\
\hline InPSA $(0,05-1,0)$ & $5,23(3,16-8,86)$ & $<0,001$ \\
pT stadium (T2a-T3b) & $1,36(1,05-1,75)$ & 0,019 \\
Gleason score (6-10) & $1,02(0,77-1,35)$ & 0,879 \\
snijranden (negatief $v$ s. positief) & $0,59(0,35-0,97)$ & 0,044 \\
FP score (1-12) & $0,92(0,85-0,99$ & 0,040 \\
tijd na RP (2-140 mnd) & $1,00(0,99-1,01)$ & 0,449 \\
\hline
\end{tabular}

\section{Conclusie}

Het effect van salvageradiotherapie na RP varieert en is afhankelijk van een aantal klinische kenmerken. Op basis van de risicofactoren kan het oncologisch effect van salvageradiotherapie voor de individuele patiënt worden ingeschat. Het PSA, het pT-stadium, de chirurgische snijranden en de mate van zenuwsparende chirurgie zijn significant gerelateerd aan de uitkomst van salvageradiotherapie. Dat zenuwsparende chirurgie in multivariate analyse gerelateerd is aan een betere respons op salvageradiotherapie vraagt om aanvullend onderzoek. Het suggereert een grotere kans op lokaal recidief ondanks dat de snijranden vrij van tumor zijn.

\section{De rol van cytologie in de follow-up na cystectomie}

\section{R. Kikkert, E. Hinsenveld, G.J. Molijn en E.B. Cornel}

ZGT Twente, locatie Almelo

\section{Introductie}

Follow-up na een cystectomie vanwege spierinvasief urotheelcelcarcinoom (MIBC) is gericht op het opsporen van een lokaal recidief, van een recidief hogere urinewegen of van metastasen op afstand. De MIBC-richtlijnen zijn niet eenduidig ten aanzien van het follow-upprotocol na een cystectomie. Radiologische diagnostiek wordt over het algemeen gedaan, hoewel er op dit moment geen gegevens van prospectieve onderzoeken beschikbaar zijn waaruit het potentiële voordeel blijkt van vroegtijdige detectie van recidiverende ziekte en de impact ervan op de overleving. De rol van urinecytologie is discutabel; in de EAU-richtlijnen van follow-up na ureter- en pyelumtumoren wordt het wel aangeraden, maar in de richtlijn na cystectomie niet. Het doel van deze retrospectieve studie is na te gaan of standaard urinecytologisch onderzoek zinvol is bij de oncologische follow-up van patiënten na een cystectomie bij MIBC.

\section{Materiaal en methode}

Alle patiënten met status na cystectomie vanwege MIBC die in de periode 2000 tot en met 2017 zijn geopereerd, wer- den geanalyseerd. Er werd onderzocht bij hoeveel patiënten tijdens de follow-up cytologie was afgenomen, bij hoeveel patiënten deze positief werd tijdens de follow-up en welke implicaties deze bevinding had voor de patiënt. Er werd ook een subanalyse gedaan op de gegevens van patiënten met positieve snijvlakken en CIS in het cystectomiepreparaat.

\section{Resultaten}

Bij 148 van de 260 patiënten (57\%) werd tijdens de follow-up cytologie afgenomen. Bij slechts vier $(0,03 \%)$ patiënten bleek de cytologie positief te zijn. Bij drie van de vier patiënten werd de cytologie echter afgenomen nadat er op de CTscan aanwijzingen waren voor een recidief. Bij vier van de $260(0,02 \%)$ patiënten was er sprake van een recidief in de urethra of de ureteren/het pyelum. Bij deze vier patiënten werd dit aangetoond met behulp van beeldvormend onderzoek en leverde cytologie geen bijdrage aan. Uit de subanalyse van patiënten met een positief snijvlak en/of CIS bleek cytologisch onderzoek tijdens de follow-up ook geen meerwaarde te hebben.

\section{Conclusie}

Deze retrospectieve analyse suggereert dat cytologisch onderzoek tijdens de follow-up van patiënten na een cystectomie vanwege MIBC geen zinnige zorg is.

\section{Zijn het urotheelcarcinoom van de hoge urinewegen en het gepaard recidief urotheelcarcinoom van de blaas klonaal gerelateerd?}

T. van Doeveren, G.J.L.H. Leenders, W.N.M. Dinjens, H.J.G. van de Werken, P.J. van Leeuwen en J.L. Boormans Erasmus MC, Rotterdam

\section{Introductie}

$\mathrm{Na}$ een radicale nefro-ureterectomie (RNU) vanwege urotheelcarcinoom (UC) van de hoge urinewegen (HUW) ontwikkelt 22-47\% van de patiënten binnen twee jaar een recidief-UC in de blaas. Een bestaande hypothese voor deze verhoogde incidentie is dat beide tumoren klonaal gerelateerd zijn; tumorcellen vanuit de HUW-tumor nestelen zich in de blaas en zo ontstaat een blaastumor (monoclonale hypothese). Een andere hypothese is dat het gehele urotheel is aangedaan, waardoor multifocale tumoren ontstaan, verspreid in de gehele tractus (oligoclonale hypothese). Wij vergeleken het genetisch profiel van zeven patiënten met een UC van de HUW en een metachroon recidief in de blaas, met als doel de klonale relatie van beide tumoren te analyseren. 


\section{Materiaal en methoden}

Aan de hand van HE-coupes werden van de tumor in de HUW en het recidief in de blaas gebieden met $>80 \%$ tumorcellen geïdentificeerd. Uit het paraffineblokje werd één pons genomen en DNA geïsoleerd. Na een kwaliteitscontrole werden beide tumoren van dezelfde patiënt vergeleken op somatische mutaties, verlies van heterozygositeit $(\mathrm{LOH})$ en allelic imbalance (AI) middels next generation targeted sequencing (NGS). Het NGS-panel betrof 41 met kanker geassocieerde genen (328 amplicons).

\section{Resultaten}

Het cohort betrof zes mannen en één vrouw, met een gemiddelde leeftijd van 65 jaar (range 50-76). Zes van de zeven HUW-tumoren hadden stadium pTa. De gemiddelde tijd tot een recidief in de blaas was 20 maanden (range 5-45). Bij één van de zeven patiënten was DNA-isolatie van het blaasrecidief niet succesvol. Bij vier van de zes overige patiënten werden gemeenschappelijke moleculaire afwijkingen geidentificeerd die sterk duiden op klonaalgerelateerde tumoren. Bij drie van deze vier patiënten kwamen ook de $\mathrm{LOH}-$ en het AI-patroon overeen. Er werden mutaties gevonden in genen die frequent gemuteerd zijn in het UC: FGFR3, PIK3CA, TP53, PTEN, TERT, KRAS, HRAS en ERBB2. Zie tabel 19.1 .

\section{Conclusie}

In deze pilotstudie werd het moleculaire profiel van het UC van de HUW en gepaarde recidieven in de blaas geanalyseerd middels NGS. De resultaten suggereren dat er twee op de drie keer sprake is van een klonale relatie tussen beide tumoren.

Tabel 19.1 Uitkomsten NGS per patiënt

\begin{tabular}{|c|c|c|c|c|c|c|c|c|}
\hline sample & $\begin{array}{l}\% \text { tumor } \\
\text { cells }\end{array}$ & $\begin{array}{l}\text { time to } \\
\text { UCB } \\
\text { (months) }\end{array}$ & $\begin{array}{l}\text { pTN } \\
\text { stadium }\end{array}$ & $\begin{array}{l}\text { diameter } \\
(\mathrm{cm})\end{array}$ & $\begin{array}{l}\text { DNA } \\
\text { conc } \\
(\mathrm{ng} / \mathrm{ul})\end{array}$ & mutations found (VAF) & $\begin{array}{l}\text { loss of heterzygosity } \\
\text { (LOH) pattern }\end{array}$ & clonality? \\
\hline normal & & & & & 34,3 & no mutations & & \\
\hline UTUC & 70 & & $\mathrm{pTaNx}$ & 3 & 21,5 & $\begin{array}{l}\text { FGFR3 p.Y373C c.118A } \\
>\text { G }(44 \%) ; \text { TERT C } 250 \mathrm{~T} \\
(53 \%)\end{array}$ & AI chr 7 & \\
\hline UCB & 60 & 2,69 & pTaNx & 0,8 & 2,69 & $\begin{array}{l}\text { FGFR3 p.S249C (38\%); } \\
\text { PIK3CA p. E545K c.1633G } \\
>\text { A }(41 \%) ; \text { TERT C228T } \\
(63 \%)\end{array}$ & $\begin{array}{l}\text { AI chr } 3 \text { (partial), chr } 5 \\
\text { (partial), chr } 19 \text { (partial); } \\
\text { LOH chr } 9 \text { (partial } \\
\text { CDKN2A locus) }\end{array}$ & no \\
\hline normal & & & & & 12,6 & no mutations & & \\
\hline UTUC & $70-80$ & & pTaNx & 2,7 & 20,6 & $\begin{array}{l}\text { FGFR3 p.S249C c.746C } \\
>\text { G }(45 \%)\end{array}$ & no deviations & \\
\hline UCB & 70 & 45 & $\mathrm{pTaNx}$ & 0,2 & 1,66 & $\begin{array}{l}\text { FGFR3 p.S249C c.746C } \\
>\text { G }(20 \%)\end{array}$ & $\begin{array}{l}\text { LOH chr 3, chr 7, chr 8, } \\
\text { chr } 11 \text { (partial); AI chr 10, } \\
\text { chr } 17 \text { (partial), chr 18, } \\
\text { chr } 19 \text { (partial) }\end{array}$ & yes \\
\hline normal & & & & & 37,1 & no mutations & & \\
\hline UTUC & 70 & & pTaN0 & 2 & 12,5 & $\begin{array}{l}\text { FGFR3 p.S249C c.746C } \\
>\text { G }(45 \%) \text { PIK3CA p. } \\
\text { E545K c.1633G > A }(24 \%) \\
\text { TERT C } 228 \mathrm{~T}(66 \%)\end{array}$ & AI chr 9 & \\
\hline UCB & $70-80$ & 28 & $\mathrm{pTaNx}$ & $0,3-0,5$ & 5,17 & $\begin{array}{l}\text { FGFR3 p.S249C c.746C } \\
>\text { G }(46 \%) \text {; TERT C228T } \\
(63 \%) ; \text { no PIK3CA } \\
\text { mutation (1335x coverage); } \\
\text { CDKN2A HD }\end{array}$ & AI chr 9 & yes \\
\hline normal & & & & & & no mutations & & \\
\hline UTUC & 70 & & $\mathrm{pTaNx}$ & 2,2 & 36,4 & TERT C250T (54\%) & $\begin{array}{l}\text { LOH chr 1, chr } 17 \text { (TP53 } \\
\text { locus); AI chr } 8, \text { chr } 17 \\
\text { (BRCA1 locus) }\end{array}$ & \\
\hline UCB & 70 & 36 & $\mathrm{pTaNx}$ & $0,2-0,5$ & 35,9 & TERT C250T (53\%) & $\begin{array}{l}\text { LOH chr 1, chr } 17 \text { (TP53 } \\
\text { locus); AI chr } 8, \text { chr } 17 \\
\text { (BRCA1 locus) }\end{array}$ & yes \\
\hline
\end{tabular}




\begin{tabular}{|c|c|c|c|c|c|c|c|c|}
\hline sample & $\begin{array}{l}\% \text { tumor } \\
\text { cells }\end{array}$ & $\begin{array}{l}\text { time to } \\
\text { UCB } \\
\text { (months) }\end{array}$ & $\begin{array}{l}\mathrm{pTN} \\
\text { stadium }\end{array}$ & $\begin{array}{l}\text { diameter } \\
(\mathrm{cm})\end{array}$ & $\begin{array}{l}\text { DNA } \\
\text { conc } \\
(\mathrm{ng} / \mathrm{ul})\end{array}$ & mutations found (VAF) & $\begin{array}{l}\text { loss of heterzygosity } \\
(\mathrm{LOH}) \text { pattern }\end{array}$ & clonality? \\
\hline normal & & & & & 28 & No mutations & & \\
\hline UTUC & 80 & & pTaNx & 2 & 25,3 & $\begin{array}{l}\text { KRAS p.G13D c. } 38 \mathrm{G}>\mathrm{A} \\
(62 \%) ; \text { PIK } 3 \text { CA p.E } 542 \mathrm{~K} \\
\text { c. } 1624 \mathrm{G}>\mathrm{A}(43 \%) ; \\
\text { ERBB2 p.S792Y c. } 2375 \mathrm{C} \\
>\text { A }(40 \%)\end{array}$ & LOH $\operatorname{chr} 8, \operatorname{chr} 9$ & \\
\hline $\mathrm{UCB}$ & $50-60$ & 9 & pTaNx & 0,25 & 1,38 & $\begin{array}{l}\text { KRAS p.G13D c. } 38 \mathrm{G}>\mathrm{A} \\
(52 \%) ; \text { PIK3CA p.E } 542 \mathrm{~K} \\
\text { c. } 1624 \mathrm{G}>\mathrm{A}(46 \%) ; \\
\text { ERBB2 p.S792Y c. } 2375 \mathrm{C} \\
>\text { A }(44 \%) \text { (a lot of low } \\
\text { frequent variants) }\end{array}$ & $\begin{array}{l}\text { LOH chr } 3, \operatorname{chr} 5 \\
\text { (partial), chr } 8, \operatorname{chr} 9 ; \text { AI } \\
\text { chr } 10, \operatorname{chr} 13, \operatorname{chr} 17, \\
\text { chr } 18\end{array}$ & yes \\
\hline normal & & & & & 7,94 & no mutations & & \\
\hline UTUC & $60-70$ & & pTaN0 & 2 & 13,6 & $\begin{array}{l}\text { HRAS p.G13R c. } 37 \mathrm{G}>\mathrm{C} \\
(44 \%)\end{array}$ & $\begin{array}{l}\text { partial LOH chr 1p, LOH } \\
\text { chr } 18\end{array}$ & \\
\hline UCB & $\begin{array}{l}\text { no tissue } \\
\text { available }\end{array}$ & 10 & pT1Nx & & & & & unknown \\
\hline normal & & & & & 0,975 & no mutations & & \\
\hline UTUC & $60-70$ & & pT2Nx & 1,5 & 11,3 & $\begin{array}{l}\text { PTEN p.D326Y c.976G > T } \\
(28 \%) ; \text { TP53 p.R273H } \\
\text { c.818G > A }(66 \%) ; \text { TERT } \\
\text { C250T }(73 \%) ; \text { EGFR } \\
\text { amplification }\end{array}$ & $\begin{array}{l}\text { LOH chr } 5, \operatorname{chr} 8, \operatorname{chr} 9, \\
\text { chr 13, chr } 17 \text { (TP53 } \\
\text { locus); AI chr 3, chr 10, } \\
\text { chr 11, chr } 18\end{array}$ & \\
\hline UCB & 50 & 5 & pTisNx & $0,2-0,5$ & 2,51 & no mutations & $\begin{array}{l}\text { AI chr } 1, \text { chr } 3 \text { (partial), } \\
\text { chr } 5 \text { (partial), chr } 8, \\
\text { chr } 9, \operatorname{chr} 10, \operatorname{chr} 11 \\
\text { (partial), chr 13, chr 17, } 18\end{array}$ & no \\
\hline
\end{tabular}

UTUC upper urinary tract urothelial carcinoma, $U C B$ urothelial carcinoma of the bladder.

\section{Langetermijnevaluatie naar de resultaten van het aanleggen van een continent katheteriseerbaar urostoma bij volwassenen bij neurogene en niet- neurogene indicaties}

\author{
I.M. Groenendijk, R. Nijman, B.F.M. Blok, J. Scheepe \\ en J. van den Hoek \\ Erasmus MC, Rotterdam
}

\section{Introductie}

Continent katheteriseerbare urostoma's (appendicovesicostoma's en monti-conduits) worden in de kinderurologie al meer dan drie eeuwen gebruikt, met gunstige langetermijnuitkomsten. Uit de schaarse literatuur blijkt dat het aanleggen van deze stoma's bij volwassenen met veel complicaties en re-operaties gepaard gaan, met vooralsnog geen goede verklaring. Het doel van dit onderzoek is het beschrijven van de langetermijnuitkomsten na het aanleggen van continent katheteriseerbare urostoma's bij volwassenen bij neurogene en niet-neurogene indicaties in twee tertiaire centra.

\section{Materiaal en methode}

De statussen van 41 patiënten met een katheteriseerbaar stoma werden bekeken. De karakteristieken, onderliggende ziektes en indicaties werden geëxtraheerd. De primaire uitkomstmaten waren het aantal en type re-operaties en complicaties. Er werd gekeken naar welke factoren een significant hoger risico op re-operaties of complicaties gaven. Tevens werden er prospectief vragenlijsten verstuurd waarin gevraagd werd naar de patient global impression of Improvement (PGI-I), continentie, lekkage en stomaproblemen.

\section{Resultaten}

29 patiënten waren vrouw, de gemiddelde leeftijd tijdens de ingreep was 32 jaar met een gemiddelde follow-up van 52 maanden. 28 patiënten hadden een neurogene blaas. Bij $51,2 \%$ van de patiënten was minstens één re-operatie nodig, na gemiddeld 10,5 maanden. Alleen een hogere leeftijd werd geïdentificeerd als risicofactor voor complicaties $\left(\chi^{2}\right.$; $p=0,041)$. De vragenlijst werd ingevuld door 24 patiënten, 
waarbij de PGI-I met gemiddeld 'veel verbetering' werd ingevuld. 11 patiënten waren volledig droog na de ingreep, 10 hadden nog minimale lekkage.

\section{Conclusies}

Het aanleggen van een continent katheteriseerbaar urostoma bij volwassenen gaat gepaard met een hoog re-operatierisico. Toch rapporteert de meerderheid van de patiënten met het urostoma dat hun situatie is verbeterd. In deze studie konden er, behalve leeftijd, vooralsnog geen risicofactoren geïdentificeerd worden. Goede patiëntcounseling is essentieel voordat een continent urostoma aangelegd wordt.

\section{1a. Risicofactoren voor additionele chirurgische ingrepen en postoperatieve complicaties bij retroperitoneale lymfeklierdissectie vanwege gemetastaseerde testistumor}

\author{
J.M. Blok, R.P. Meijer, H.G. van der Poel, A. Bex, S. Horenblas \\ en J.L.H.R. Bosch \\ UMC Utrecht, Utrecht; Antoni van Leeuwenhoek, Amsterdam
}

\section{Introductie}

Patiënten met een restmassa na behandeling met chemotherapie vanwege een gemetastaseerde testistumor worden behandeld met een verwijdering van de restmassa of een retroperitoneale lymfeklierdissectie (RPLKD). Dit is een uitgebreide procedure met een risico op additionele chirurgische interventies en complicaties. Wij onderzochten welke factoren voorspellend zijn voor een additionele ingreep en postoperatieve complicaties.

\section{Materiaal en methoden}

Tussen 2002 en 2016 werden 107 patiënten behandeld met een open RPLKD na chemotherapie vanwege een gemetastaseerde testistumor in twee tertiaire centra. Additionele interventie werd gedefinieerd als een chirurgische interventie die tijdens de RPLKD werd uitgevoerd en nodig was voor een adequate resectie. Risicofactoren werden geïdentificeerd met univariabele en multivariabele binaire logistische regressieanalyse.

\section{Resultaten}

Bij 34 patiënten $(31,8 \%)$ werden 52 additionele ingrepen uitgevoerd. Een partiële resectie van de $\mathrm{m}$. psoas werd het meest uitgevoerd ( $n=10 ; 9,3 \%)$, gevolgd door nefrectomie $(n=8 ; 7,5 \%)$ en resectie/reconstructie van de vena cava inferior (IVC) $(n=8 ; 7,5 \%)$. Een vasculaire ingreep werd bij 20 patiënten verricht $(18,7 \%)$. Bij 14 patiënten $(13,1 \%)$ werden 16 postoperatieve complicaties Clavien-Dindo-graad $\geq 3$ vastgesteld. Bij univariabele analyse was additionele in- terventie geassocieerd met IGCCCG intermediate/poor risk, $>3$ chemocycli en grootte van de restmassa. Bij multivariabele analyse was additionele interventie significant geassocieerd met grootte van de restmassa $(\mathrm{OR}=1,18 ; 95 \%-\mathrm{BI}=$ $1,06-1,32 ; p=0,004)$ en intermediate/poor risk $(\mathrm{OR}=3,70$; $95 \%$-BI $=1,38-9,91 ; p=0,009)$. Postoperatieve complicatie was significant geassocieerd met grootte van restmassa (OR $=1,21 ; 95 \%-\mathrm{BI}=1,07-1,38 ; p=0,003)$ en IVC/aorta-interventie $(\mathrm{OR}=5,08 ; 95 \%-\mathrm{BI}=1,14-22,60 ; p=0,033)$.

\section{Conclusie}

Bij een derde van de RPLKD-patiënten is een additionele chirurgische interventie nodig. De grootte van de restmassa en de IGCCCG-risicoclassificatie zijn geassocieerd met de noodzaak voor een additionele ingreep. Grootte van de restmassa en vasculaire interventie zijn geassocieerd met een postoperatieve complicatie.

\section{1b. Risicofactoren voor intraoperatief vaatletsel bij retroperitoneale lymfeklierdissectie vanwege gemetastaseerde testistumor}

J.M. Blok, R.P. Meijer, H.G. van der Poel, A. Bex,

J.L.H.R. Bosch en S. Horenblas

UMC Utrecht, Utrecht; Antoni van Leeuwenhoek, Amsterdam

\section{Introductie}

In een deel van de patiënten die met chemotherapie zijn behandeld voor een gemetastaseerde testistumor, persisteert een retroperitoneale restmassa. Deze restmassa wordt vervolgens gereseceerd, al dan niet met een full-template retroperitoneale lymfeklierdissectie (RPLKD). De desmoplastische reactie tussen de restmassa en aanliggende vaatstructuren maakt dit tot een complexe procedure met risico op perioperatieve morbiditeit. In dit onderzoek analyseerden we welke risicofactoren geassocieerd zijn met intraoperatief vaatletsel.

\section{Materiaal en methoden}

De gegevens van 107 patiënten die tussen 2002 en 2016 een open ingreep vanwege restletsel na chemotherapie voor een testistumor hebben ondergaan in twee tertiaire centra werden geanalyseerd. Bij 105 patiënten waren de data volledig. Alleen vaatletsel van de grote vaten waarvoor een interventie (e.g. overhechting, reconstructie) geïndiceerd was, werd in beschouwing genomen. Vasculaire interventies die noodzakelijk waren voor een adequate resectie niet. Risicofactoren voor intraoperatieve vasculaire complicaties werden geïdentificeerd middels univariabele en multivariabele binaire logistische regressie. 


\section{Resultaten}

Bij 39 patiënten (36.4\%) ontstond intraoperatief een vaatlaesie. Een laesie van de vena cava kwam het meest voor (15 patiënten; 14,1\%), gevolgd door de aorta (11 patiënten; $10,3 \%$ ) en de v. renalis ( 9 patiënten; 8,4\%). In 14/39 gevallen werd de vaatchirurg om assistentie gevraagd en in 7 gevallen werd een prothese ingehecht. Bij 6/39 patiënten $(15,4 \%)$ die met 3 chemocycli waren behandeld, trad intraoperatief vaatletsel op. Dit was ook het geval bij 33/66 patienten $(50 \%)$ die met $>3$ chemocycli waren behandeld. Bij univariabele analyse was intraoperatief vaatletsel geassocieerd met IGCCCG intermediate/poor risk, > 3 chemocycli, grootte van restmassa en retroperitoneale histologie. Bij multivariabele analyse waren $>3$ chemocycli significant geassocieerd met intraoperatief vaatletsel (OR $=4,1 ; 95 \%$-BI 1 , $12-15,08 ; p=0,034)$.

\section{Conclusie}

Intraoperatief vaatletsel bij RPLKD is geassocieerd met $>3$ cisplatin-houdende chemocycli.

\section{Evaluatie van laparoscopische nefrectomie bij participatie van aios}

\author{
B.M. Privé, M.D.H. Kortleve en J.P.A. van Basten \\ CWZ, Nijmegen; Ziekenhuis Gelderse Vallei, Ede
}

\section{Introductie}

De laparoscopische nefrectomie is de meest uitgevoerde laparoscopische ingreep door arts-assistenten in opleiding tot uroloog (aios). Echter, er is weinig bekend over de invloed van een aios op de per- en postoperatieve uitkomsten van deze operatie. Het doel van dit onderzoek was vast te stellen welke mogelijke invloed een aios heeft op de operatie-uitkomst.

\section{Methoden}

Retrospectief werden alle patiënten die een laparoscopische nefrectomie hadden ondergaan tussen 2010 en 2018 geanalyseerd. Demografie, datum van operatie, per- en postoperatieve resultaten alsmede complicaties werden vastgelegd. Patiënten werden opgedeeld in twee groepen; één waarbij aios geparticipeerd hadden tijdens de ingreep en één groep waarbij de uroloog (Uro) alleen, zonder aios, de ingreep had uitgevoerd.

\section{Resultaten}

229 patiënten werden geïncludeerd. 78 patiënten werden geopereerd met een aios en 151 zonder. Beide groepen waren homogeen aangaande leeftijd, geslacht, BMI, ASA, Charlson comorbidity index, links-rechts lokalisatie en tumorstadium. Tussen beide groepen werden geen significante verschillen gemeten in bloedverlies (aios 87,5 ml; IQR $=50-200 \mathrm{ml} v s$. Uro $100 \mathrm{ml}$; IQR $=50-200 \mathrm{ml}$ ), intraoperatieve complicaties (aios $10,3 \% v s$. Uro $6 \% ; p=0,24$ ), conversie naar open nefrectomie (aios 6,4\% vs. Uro 6\%) en postoperatieve complicaties Clavien $>2$ (aios 3,9\% vs. Uro 4,6\%). Wel duurde de ingreep gemiddeld 20 minuten langer indien een aios meedeed (gemiddeld $130 \mathrm{~min}$. SD +/- $39 \mathrm{~min} ; p=<0,001$ ). Zie tabel 22.1.

\section{Conclusie}

De uiteindelijke invloed van een aios op de operatie-uitkomst is beperkt. Het is veilig om samen met een aios een laparoscopische nefrectomie uit te voeren. Wel is het van belang rekening te houden met extra operatietijd.

Tabel 22.1

\begin{tabular}{|c|c|c|c|}
\hline & met aios $(n=78)$ & zonder aios (Uro) $(n=151)$ & $p$ \\
\hline mediane leeftijd in jaren (IQR) & $67(60-73)$ & $68(59-74)$ & 0,76 \\
\hline tumorgrootte in $\mathrm{cm}(\mathrm{SD})$ & $5,7(2,6)$ & $5,9(2,9)$ & 0,57 \\
\hline benigne nefrectomie & $12(15,4 \%)$ & $17(11,3 \%)$ & - \\
\hline radicale nefrectomie & $66(84,6 \%)$ & $134(88,7 \%)$ & 0,374 \\
\hline gemiddelde operatietijd in min. (SD) & $130(+/-39)$ & $110(+/-34)$ & $<0,001$ \\
\hline mediane geschat bloedverlies in $\mathrm{ml}$ (IQR) & $87,5(50-200)$ & $100(50-200)$ & 0,835 \\
\hline intra-operatieve laesies & $8(10,3 \%)$ & $9(6,0 \%)$ & 0,24 \\
\hline conversie naar open & $5(6,4 \%)$ & $9(6 \%)$ & 1 \\
\hline geen complicaties: & $55(70,5 \%)$ & $111(73,5 \%)$ & 0,532 \\
\hline Clavien-Dindo-graad 3 & $2(2,6 \%)$ & $4(2,6 \%)$ & 1 \\
\hline Clavien-Dindo-graad 4 & $1(1,3 \%)$ & $3(2,0 \%)$ & - \\
\hline Clavien-Dindo-graad 5 & 0 & 0 & - \\
\hline
\end{tabular}




\section{Functionele en oncologische langetermijn- uitkomsten van salvagecryochirurgie voor lokaal recidief prostaatcarcinoom: singlecenter cohortanalyse van 12 jaar}

\section{Exterkate, D.M. Somford en H. Vergunst \\ CWZ, Nijmegen}

\section{Introductie}

Een meerderheid van de patiënten met een lokaal recidief prostaatkanker $(\mathrm{PCa})$ na primaire behandeling start met androgeendeprivatietherapie met morbiditeit en verminderde kwaliteit van leven tot gevolg. Salvagecryochirurgie (SCC) is een zich evoluerende minimaal invasieve behandeltechniek voor het lokaal recidief-PCa. Het ontbreekt echter aan langetermijndata van functionele en oncologische uitkomsten. Deze studie toont de functionele en oncologische langetermijnresultaten van een hoogvolumecentrum met twaalf jaar klinische ervaring met SCC.

\section{Materiaal en methoden}

173 mannen die werden behandeld middels derdegeneratie-cryochirurgie (mei 2006 - juli 2018) werden retrospectief geanalyseerd. Een biochemisch recidief was gedefinieerd als PSA nadir + 2 ng/ml (Phoenix-definitie). 160 patiënten konden worden gestratificeerd op basis van de initiële d'Amicorisicoclassificatie. Postoperatieve PSA-controles vonden iedere 3-6 maanden plaats. Complicaties werden gescoord middels gevalideerde vragenlijsten en op basis van poliklinische rapportages.

\section{Resultaten}

Mediane follow-up was 36 maanden $(\mathrm{IQR}=18-66)$. De gemiddelde leeftijd tijdens SCC was $67,8 \pm 5,7$ jaar. De bioche-

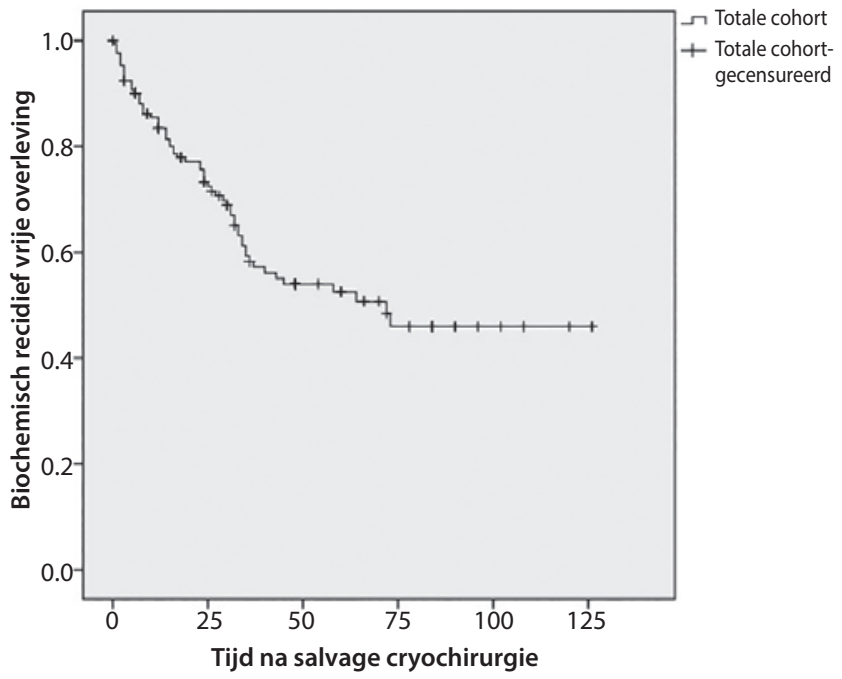

misch recidiefvrije overleving (BRFS) van het gehele cohort ( $n=173$ ) na een mediane follow-up van 36 maanden was $58,3 \% .13(72,2 \%)$ patiënten in de laagrisicogroep $(n=18)$, 25 patiënten $(67,6 \%)$ in de matigrisicogroep $(n=37)$ en 70 $(66,7 \%)$ patiënten in de hoogrisicogroep $(n=105)$ hadden een BRFS. In het eerste jaar na SCC trad bij 23,1\% van de mannen (al of niet tijdelijk) voor het eerst urine-incontinentie op en bij 32,9\% voor het eerst erectiele disfunctie. Totaal 21 mannen ontwikkelden een fistel binnen 30 maanden (gemiddeld na $10 \pm 9$ maanden). Dit waren 14 recto-urethrale of -vesicale fistels, 5 cutane fistels en bij twee patiënten kwamen beide soorten fistels voor.

\section{Conclusie}

Deze retrospectieve single-center analyse over een periode van 12 jaar toont acceptabele langetermijn-oncologische resultaten van SCC. Het optreden van significante complicaties, zoals urine-incontinentie en fistels moet echter niet onderschat worden. Een zorgvuldige selectie van welke patiënten voor behandeling in aanmerking komen, is van groot belang.

\section{PTNS, still going strong of toch een ever ending story?}

M. te Dorsthorst en M. van Balken

Rijnstate, Arnhem

\section{Introductie}

Percutaneous tibial nerve stimulation (PTNS) is een minimaal-invasieve vorm van neuromodulatie die vooral wordt gebruikt ter behandeling van een overactieve blaas (OAB). Uit de literatuur blijkt dat PTNS bij 60-80\% van de patiën-

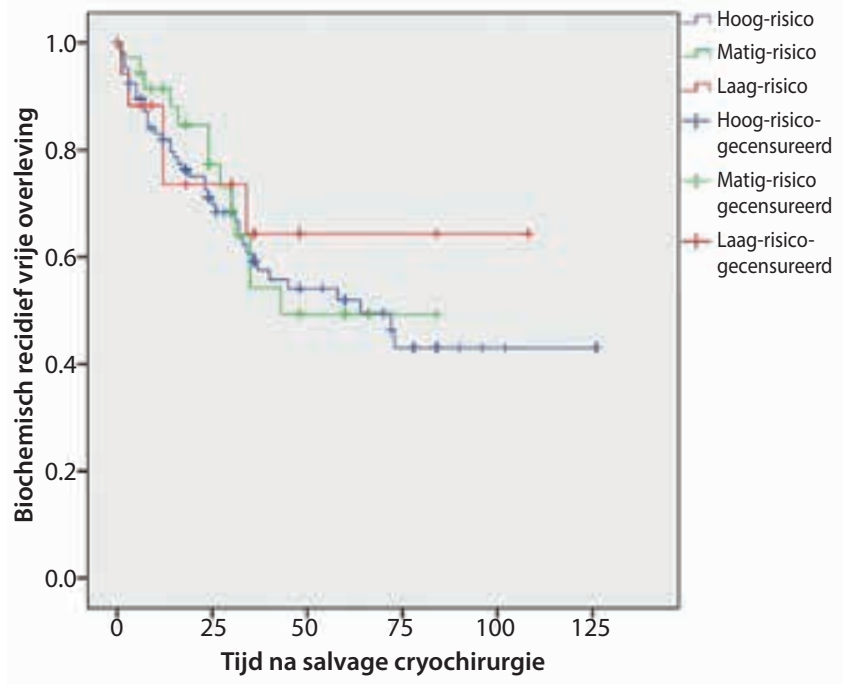

Figuur 23.1 Kaplan-Meijer-plots 
ten zorgt voor klachtenreductie. Nadeel is de noodzaak tot onderhoud. Data over uitkomsten in de dagelijkse praktijk zijn, net als die over de langetermijneffecten, schaars.

\section{Materiaal en methode}

Alle patiënten die vanaf 2008 in ons centrum PTNS ondergingen, werden in dit retrospectieve onderzoek geïncludeerd. Genoteerd werden de indicatie voor PTNS, het moment waarop en de reden van staken, alsmede de vervolgbehandeling. De Kaplan-Meier-curves (SPSS) werden gebruikt om het verschil tussen groepen weer te geven. Hierbij werd onderscheid gemaakt tussen: de gehele groep (A), de onderhoudsgroep $(C)$ en de onderhoudsgroep minus patiënten die waren gestopt omdat ze verhuisden, thuis PTNS doorzetten, overleden of geen klachten meer hadden (C) en de onderhoudsgroep minus succesvol behandelde patiënten die toch stopten vanwege de belasting (pijn, het komen) (D).

\section{Resultaten}

402 patiënten die tussen 2008 en juli 2018 startten met PTNS werden geïncludeerd ( $70 \%$ vrouw). Indicatie was vooral OAB-wet $(54 \%)$ of $-d r y(29 \%)$. De mediane follow-up $(\mathrm{mFU})$ van de totale groep was vier maanden (fig. 1A; maximaal 112 maanden). 228 patiënten (57\%) continueerden de behandeling na 12 weken (fig. 1B). 48 patiënten stopten omdat ze geen klachten meer hadden, thuis verder behandelden, verhuisden of omdat ze overleden (fig. 1C). Zonder hen was de mFU 18 maanden. Fig. 24D is het beeld van de patiënten
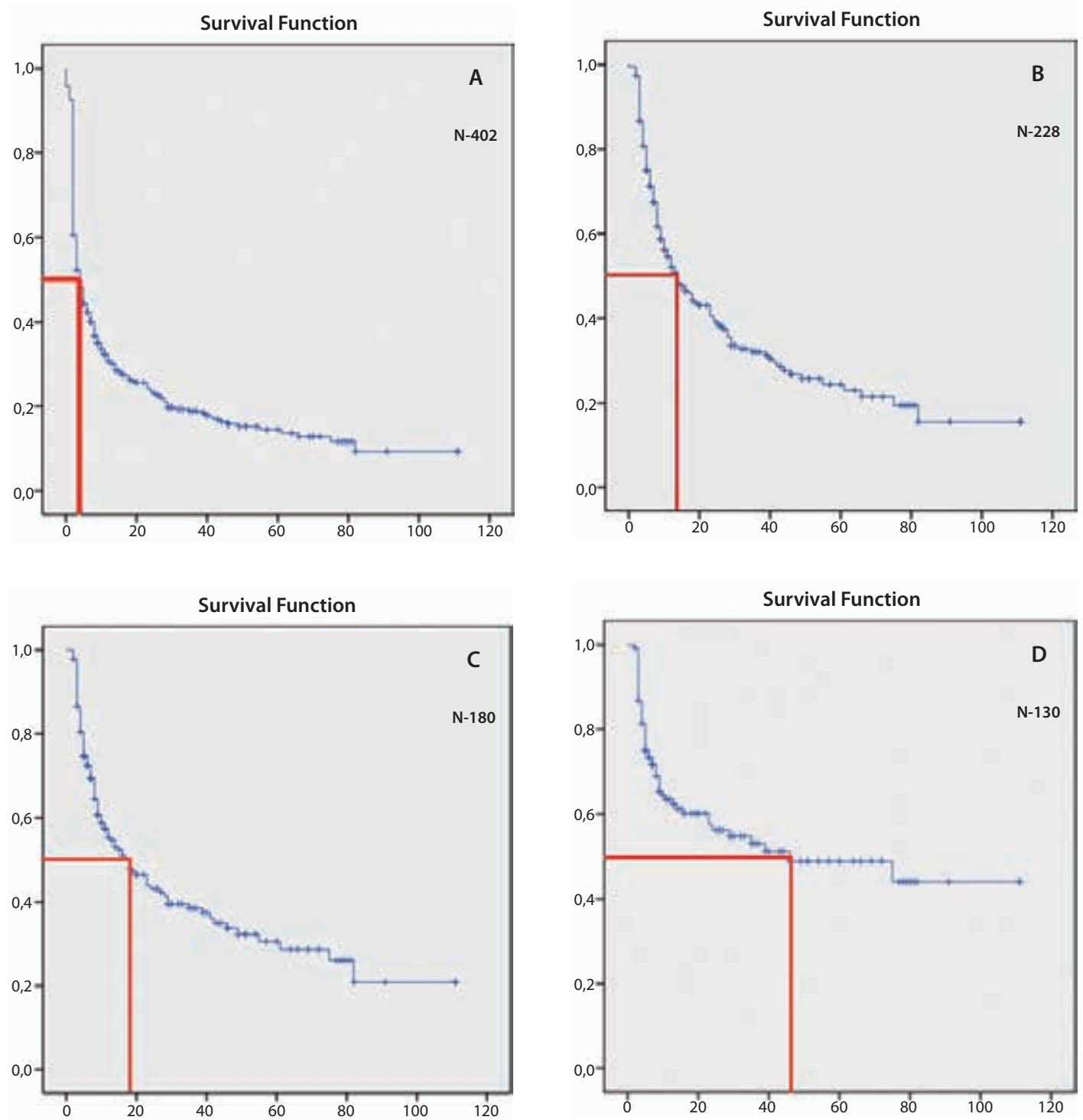

Figuur 24.1 A. Gehele groep B. Onderhoudsgroep C. Onderhoudsgroep minus patiënten stopten omdat ze verhuisden, thuis PTNS doorzetten, overleden waren of geen klachten meer hadden D. De onderhoudsgroep minus succesvolle patiënten die toch stopten vanwege de belasting. 
die stopten met de behandeling, hoewel die succesvol was, vanwege de belasting ervan $(\mathrm{mFU}=46$ maanden $)$. Wie initieel of tijdens onderhoud PTNS staakte, ging in de meeste gevallen over op Botox (14\%), Mirabegron (10\%) of geen behandeling (57\%).

\section{Conclusie}

Onze studie over PTNS in de dagelijkse praktijk laat zien dat succespercentages overeenkomen met de literatuur. Met een maximale FU van bijna 10 jaar blijkt ook op de lange termijn PTNS succesvol. Dit feit, alsmede het feit dat er een groep is die, ondanks succes, toch moet afhaken omdat de behandeling te belastend is, ondersteunen de ontwikkeling van een implantaat als vervanging voor de percutane route.

\section{De partiële nefrectomie, laparoscopisch versus robotgeassisteerd}

P.C. Wesselman van Helmond en J.B.W. Rietbergen

Franciscus Gasthuis, Rotterdam

\section{Introductie}

Bij de behandeling van niertumoren gaat de voorkeur uit naar niersparende therapie, mits de grootte en positie van de tumor dit toelaat. Niersparende chirurgie bestaat in veel centra uit een laparoscopische partiële nefrectomie (LPN). In Nederland krijgt de robotgeassisteerde partiële nefrectomie (RAPN) echter een steeds grotere plaats. Een inschatting van de complexiteit van de tumor en daarmee het operatierisico kan worden gemaakt met behulp van de radiologische RENAL-score, ingedeeld in een laag-, een middel- en hoogrisico categorie. In deze retrospectieve studie werden de resultaten vergeleken van de laparoscopische en de robotgeassisteerde partiële nefrectomie.

\section{Methoden}

Er werd een statusonderzoek verricht bij 170 patiënten die van juni 2005 tot en met augustus 2015 een partiële nefrectomie ondergingen. Het resultaat werd bepaald aan de hand van de operatieduur, de ischemietijd, het peroperatief bloedverlies, conversie naar totale of open nefrectomie, complicaties, positieve snijvlakken, de postoperatieve nierfunctie en de nierfunctie een jaar na de operatie. Aan de hand van de preoperatieve CT-scan werd de RENAL-score bepaald. Per risicogroep werd het verschil in resultaat bepaald tussen de LPN en de RAPN.

\section{Resultaten}

112 patiënten ondergingen een LPN en 58 een RAPN. Beide groepen hadden vergelijkbare patiënt- en tumorkarakteristieken. 89 patiënten hadden een tumor met een laag operatierisico, 59 een met een gemiddeld operatierisico en tien met een hoog operatierisico. In de laag- en middel-risicogroep had de RAPN een kortere ischemietijd (resp. 8,21 min $v s$. $13,41 \mathrm{~min} ; p=0,001$ en 12,08 $\min v s .16,35 \mathrm{~min} ; p=0,049$ ). Dit kan mogelijk worden verklaard door een aantal ingrepen zonder ischemie bij de RAPN. In de middelrisicogroep was de operatieduur korter bij de LPN dan bij de RAPN $(151,26$ $\min v s$. $180,08 \mathrm{~min} ; p=0,008)$. Er was geen significant verschil tussen de overige factoren.

\section{Conclusie}

Zowel de laparoscopische als de robotgeassisteerde partiële nefrectomie zijn geschikte opties voor niersparende chirurgie bij niertumoren. Het voordeel van de robotchirurgie is een kortere ischemieduur, met zelfs de mogelijkheid tot operaties zonder ischemie.

\section{Langetermijnresultaten van de conservatieve behandeling van urotheelcarcinoom in de hoge urinewegen}

\author{
D.J.H. Baas, M.T.J. Bus en E.P. van Haarst \\ OLVG, Amsterdam
}

\section{Introductie}

Radicale nefro-ureterectomie (RNU) is standaard bij de behandeling van urotheelcarcinoom in de hoge urinewegen (UTUC), maar heeft direct invloed op de nierfunctie. De EAU-richtlijn van 2017 adviseert laagrisicotumoren conservatief te behandelen middels endoscopische laserablatie. Het doel van deze studie is het evalueren van langetermijnresultaten bij patiënten die zijn behandeld voor UTUC in het OLVG. Patiënten werden behandeld middels RNU, endoscopische laserablatie volgens de EAU-richtlijn (electief) of buitenprotocollair endoscopische laserablatie (imperatief). Deze drie groepen werden geëvalueerd.

\section{Materiaal en methoden}

Het betreft een retrospectief onderzoek. Patiënten die voldeden aan de inclusiecriteria $(n=75)$ werden verdeeld in drie groepen. In groep 1 de imperatief conservatief behandelde patiënten $(n=21)$, in groep 2 de electief conservatief behandelde patiënten $(n=12)$ en in groep 3 de patiënten die een RNU ondergingen $(n=42)$. De gegevens van de patiënten werden geanalyseerd op het optreden van een of meer van de volgende gebeurtenissen: lokaal recidief, recidief in de blaas, progressie van ziekte, RNU, metastasen en overleving. Kaplan-Meier-curves werden gebruikt om de verschillen tussen de drie groepen te analyseren.

\section{Resultaten}

De gemiddelde leeftijd van patiënten was 70 jaar (44-93), met een gemiddelde follow-up van 34 (3-115) maanden. In 
groep 1 werd 122 keer een uretero-renoscopie (URS) verricht, gemiddeld 5,8 per patiënt. In groep 2 waren dat er 73, gemiddeld 6,1 per patiënt. We vonden geen significant verschil tussen de drie groepen voor het optreden van de genoemde uitkomstmaten. Bij 14 (42\%) van de 33 conservatief behandelde patiënten (groep 1 en 2) ontstond een lokaal recidief. Hiervoor ondergingen zeven patiënten alsnog een RNU. In de electief behandelde groep kreeg geen van de patiënten metastasen en trad geen sterfte op die was gerelateerd aan UTUC .

\section{Conclusie}

Conservatieve behandeling van UTUC is een veilig alternatief voor laagrisicotumoren. Er was geen verschil tussen de conservatief behandelde groepen, waardoor er ruimte is om de definitie van laagrisicotumoren in de richtlijn te verruimen.

\section{Peniskankercentrum Oost-Nederland: evaluatie van de eerste 51 patiënten}

\author{
B.K. Kroon, P.C. Weijerman, J. Rütter, R. Koot en T. Rijnders
} Rijnstate, Arnhem

\section{Introductie}

Met als doel de regionale zorg rondom de peniskankerpatiënt te optimaliseren, is in 2014 in ons centrum gestart met de behandeling van peniskanker. Diverse behandelingen worden in ons centrum uitgevoerd met verwijzing naar het referentiecentrum (AVL), alleen zo nodig. Het doel van dit onderzoek is om de uitkomsten hiervan te evalueren.

\section{Materiaal en methoden}

Tussen juli 2014 en juli 2018 werden in ons centrum 51 opeenvolgende patiënten met de diagnose peniskanker behandeld. Patiënt- en tumorkarakteristieken en uitkomsten van behandeling werden prospectief verzameld.

\section{Resultaten}

De behandeling van de primaire tumor bestond uit partiële amputatie (22x), lokale excisie (20 x), volledige amputatie (5x) en radiotherapie (3x). Bij één patiënt was een partiële amputatie reeds elders verricht. Bij vijf patiënten was sprake van een positief snijvlak waarvoor re-excisie werd verricht en twee keer was sprake van een lokaal recidief. Er werd 35 keer een biopsie van de sentinel node uitgevoerd. Deze node was bij vier patiënten tumorpositief. Tijdens een gemiddelde follow-up van 14 maanden was geen sprake van een tumorrecidief in de liezen; de sensitiviteit van de sentinel-nodeprocedure was derhalve $100 \%$. Complicaties traden op bij 9 mannen (7x Clavien II, 2x Clavien III). Er werd vijf keer een liesklierdissectie uitgevoerd. Vijf patiënten $(10 \%)$ werden doorverwezen naar het AVL, (4x omdat specifieke expertise vereist was en $1 \mathrm{x}$ op verzoek van de patiënt).

\section{Conclusie}

$90 \%$ van de peniskankerpatiënten kunnen in hun eigen regio behandeld worden. De uitkomsten in ons centrum zijn vergelijkbaar met de resultaten uit de literatuur van hoogvolume-expertisecentra. Naar onze menig is in Nederland plaats voor drie regionale centra en één landelijk referentiecentrum voor de behandeling van het peniscarcinoom. Door deze vorm van netwerkgeneeskunde kan 'zorg dichtbij waar mogelijk en verder weg waar nodig' (visiedocument FMS 2025 ) in de praktijk gebracht worden voor de -vaak oude en kwetsbare - patiënten met deze tumorsoort.

\section{Wat doet de blaas als we ouder worden? Detrusorcontractiliteit in relatie tot leeftijd en geslacht}

P.F.W.M. Rosier, C.S. Ten Donkelaar en L.M.O. de Kort UMC Utrecht, Utrecht

\section{Introductie}

Veroudering gaat gepaard met verlies van spiermassa, wellicht ook van de blaasspier. Lower urinary tract symptoms (LUTS) bij ouderen zouden verklaard kunnen worden door verminderde contractiekracht van de blaasspier. Wij onderzochten de relatie tussen detrusorcontractiekracht, leeftijd en geslacht.

\section{Materiaal en methoden}

In een cross-sectionele studie werd een analyse uitgevoerd van opeenvolgende druk-flowstudies van patiënten $>18$ jaar met LUTS die geen neurologische of congenitale aandoening hadden. Bekeken werden de maximale stroomsnelheid $\left(\mathrm{Q}_{\max }\right)$, detrusordruk tijdens $\mathrm{Q}_{\max }\left(\mathrm{Pdet}_{\mathrm{Qmax}}\right)$, urethrale weerstand (URA), blaasuitgangsobstructie-index (BOOI), maximale blaascontractiekracht $\left(\mathrm{W}_{\max },[(\mathrm{Pdet}+\mathrm{a})(\mathrm{V}+\mathrm{b})-\mathrm{ab}] / 2 \pi\right)$ en blaascontractiliteitindex (BCI, $\left.\mathrm{P}_{\text {det }} \mathrm{Q}_{\max }+5 \mathrm{Q}_{\max }\right)$. Uitkomsten werden gerelateerd aan leeftijd en geslacht. Leeftijd werd ingedeeld in decades (20-29, 30-39, etc).

\section{Resultaten}

Er werden 1157 druk-flowstudies geïncludeerd, waarvan 369 van vrouwen. Mannen hadden een hogere $\operatorname{Pdet}_{\mathrm{Qmax}}$ en lagere $\mathrm{Q}_{\max }$ dan vrouwen. URA en BOOI waren hoger bij oudere dan bij jongere mannen, bij vrouwen was er geen verschil. De Pdet ${ }_{\text {Qmax }}$ was lager bij vrouwen dan bij mannen en was lager bij oudere dan bij jongere vrouwen. De $\mathrm{W}_{\max }$ en de BCI waren lager bij hogere leeftijd; bij vrouwen was dit meer uitgesproken dan bij mannen. 


\section{Conclusie}

Blaascontractiekracht is lager op hogere leeftijd, vooral bij vrouwen. Bij oudere mannen wordt een hogere uitgangsweerstand gevonden. Mogelijk speelt dit een rol bij het intact houden van de blaascontractiliteit.

\section{Niet-resorbeerbare bulking agent bij postprostatectomie stressincontinentie}

M.J.M. Geerkens, P. Venema, J.A. Nieuwenhuijzen en G. Pigot Amsterdam UMC, locatie VUmc, Amsterdam

\section{Introductie}

Het injecteren van bulkmateriaal heeft een beperkte rol bij de behandeling van stress-urine-incontinentie bij mannen, deels vanwege het tijdelijke effect ervan. Wij onderzochten retrospectief de effectiviteit en veiligheid van een niet-biologisch-afbreekbare bulking agent, bestaande uit polydimethylsiloxane (PDMS) polymeer, tetrapropoxysilane en titaniumdioxide bij de stressincontinente (PP-SUI) man.

\section{Materiaal en methoden}

Geanalyseerd werden 17 patiënten (gem. leeftijd 72,6 jaar; range 60-80) die tussen november 2015 en april 2016 met de bulkinjecties werden behandeld vanwege PP-SUI. Behandeling vond plaats in dagbehandeling en onder algehele anesthesie. Het bulkmateriaal werd transperineaal en onder cystoscopische controle aan weerszijden caudolateraal van de urethrasfincter geïnjecteerd. Bij onvoldoende effect werd de behandeling herhaald. De patiënten werden postoperatief na 6, 12 en 24 maanden telefonisch benaderd en gevraagd naar het aantal gebruikte inleggers per dag in vergelijking met het preoperatief gebruik, en het percentage subjectieve verbetering van de continentie.

\section{Resultaten}

10 mannen werden eenmalig behandeld, zes tweemaal en drie driemaal. $\mathrm{Na}$ een follow-up van 24 maanden gaf $25 \%$ van de patiënten aan droog te zijn. 53\% van alle patiënten gaf een verbetering van continentie aan, $31 \%$ ervoer geen verandering en $19 \%$ gaf een verslechtering aan. In totaal werden drie complicaties gezien: een urineweginfectie, de novo ontstane urgency en een erosie, waarvoor het bulkmateriaal moest worden verwijderd.

\section{Conclusies}

Injectietherapie met dit bulkmateriaal heeft een beperkt effect bij de behandeling van mannen met stress-urine-incontinentie. Meerdere behandelingen zijn mogelijk. Bij een verbetering van de incontinentie lijkt het effect langdurig. Een grotere prospectieve studie is nodig om de waarde van de behandeling van stressincontinentie met dit bulkmateriaal te evalueren. 